\title{
FUNDAMENTOS ONTOLÓGICOS
}

EN LA FILOSOFÍA ANDINA DE JOSEF ESTERMANN

JASSER GIOVANNY SANDOVAL MIRANDA

\author{
UNIVERSIDAD SANTO TOMÁS \\ FACULTAD DE FILOSOFÍA Y LETRAS \\ MAESTRÍA EN FILOSOFÍA LATINOAMERICANA \\ BOGOTÁ \\ 2018
}


FUNDAMENTOS ONTOLÓGICOS

EN LA FILOSOFÍA ANDINA DE JOSEF ESTERMANN

JASSER GIOVANNY SANDOVAL MIRANDA

DIRECTOR: JUAN CEPEDA H.

DOCTOR EN FILOSOFÍA

UNIVERSIDAD SANTO TOMÁS

FACULTAD DE FILOSOFÍA Y LETRAS

MAESTRÍA EN FILOSOFÍA LATINOAMERICANA

BOGOTÁ

2018 
Dedicado a

Kuntur y Camilo, sin ustedes el movimiento carece de sentido.

Mama y Papá, porque el querer saber pasa siempre por ustedes.

Julián, quien me enseñó a leer, de ahí le debo todo

Latinoamérica, donde lo que mejor se puede hacer es rebelarse y pensar/hacer diferente 


\section{Agradecimientos}

A Dios y todas sus bellas formas que tiene de nombrarse y manifestarse; dentro de las cuales me ha dado los mejores consejos y los mejores problemas para solucionar.

Taita Yagé, por la claridad para culminar este llamado de la sabiduría; Taita Tabaco, fiel compañero de noches de lectura y escritura; Mama Chicha, generadora de ideas y exploradora de la palabra para compartir y crear; Madre Noche, donde parí mis ideas.

A la Secretaría de Educación de Bogotá Humana; con su ayuda ha sido posible hacer esta trayectoria académica y de vida.

A la Universidad Santo Tomás y todos aquellos profesores maravillosos que me guiaron, inspiraron y creyeron en mí. A Juan Cepeda H. quien con su apoyo, disciplina y humildad ha contribuido a la filosofía latinoamericana y me ha acompañado en mi proceso de abrir senderos del pensar en este suelo.

A mi familia, quienes me dieron todo lo que soy, desde mi espíritu hasta mi cuerpo latinoamericano.

A mis compañeros y amigos, en especial a Jhony y Laura. ¿Quiénes seríamos sin las calles desgastadas bajo nuestros pies, sin las mil palabras escuchadas, sin las mil dudas que solo nosotros sabíamos que no sabíamos y aun así nos respondimos, sin los mil brindis, sin los mil cariños?

Al mundo de la vida. 


\section{RESUMEN}

El presente trabajo de investigación se propone hacer un aporte significativo a la ontología y la metafísica desde una perspectiva geo-cultural situada en Latinoamérica, más precisamente en los Andes. A través de un examen hermenéutico textual de la Filosofía Andina de Josef Estermann se pretende hallar una forma de decir el ser, de aportar más elementos a la búsqueda por lo que es y el sentido de ser.

Apoyado en un recorrido histórico de la ontología en América latina, la descripción de lo andino en Josef Estermann y las categorías de la pachasofía -como alternativa andina de la filosofía-, esta investigación revela un modo del ser en el que lo sustancial, único y autónomo pasa a una segunda instancia y se da prioridad ontológica a la relacionalidad, la pacha y la chakana como los fundamentos que constituyen el ser desde la situación andina.

\section{Palabras clave}

Ontología, andino, relacionalidad, filosofía andina, Chakana, Pacha. 
TABLA DE CONTENIDO

$\begin{array}{ll}\text { INTRODUCCIÓN } & 7\end{array}$

1. ONTOLOGÍA EN AMÉRICA LATINA 12

1.1 La ontología en el estar 13

1.2 La metafísica desde Latinoamérica $\quad 18$

$\begin{array}{ll}1.3 \text { La ontología en la habencia } & 23\end{array}$

1.4 Ontología simbólica $\quad 29$

1.5 El ser y la existencia en categorías quechuas 34

1.5.1 Kay, el ser $\quad 35$

1.5.2 Kashay, el existir $\quad 36$

1.6 Ontología animista en el Amazonas $\quad 38$

1.7 El sentipensar ontológico, una propuesta sustentada en la afectividad 42

2. LO ANDINO EN LA FILOSOFÍA ANDINA DE JOSEF ESTERMANN Y SUS FUNDAMENTOS ONTOLÓGICOS 48

2.1 El fenómeno de lo andino 48

2.1.1 Momento de la filosofía de Estermann 49

2.1.2 El origen del problema de la Filosofía Andina de Estermann, hasta dónde puede llegar su propuesta $\quad 52$

2.1.3 Lo andino como fenómeno, un problema para describir $\quad 54$

2.1.3.1 Lo andino como geográfico

2.1.3.2 Lo andino como étnico $\quad 56$

2.1.3.3 Lo andino como inca $\quad 57$

2.1.4 El método para la filosofía andina $\quad 59$

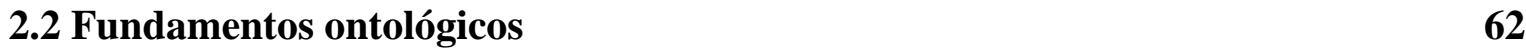

2.2.1 La relacionalidad de todo, un modo de ser 63

$\begin{array}{ll}\text { 2.2.2 Pacha, la totalidad relacional } & \mathbf{7 5}\end{array}$

2.2.3 La chakana, realización fáctica de la relacionalidad 77

2.2.3.1 La relacionalidad entre el hombre/mujer andino y su acceso al mundo, la chakana filosófica para conocer el ser en su totalidad

2.2.3.2 Ckakana celebrativa, la ubicación del hombre/mujer andino

3. CONCLUSIONES

$\begin{array}{ll}\text { Referencias bibliográficas } & 94\end{array}$ 


\section{INTRODUCCIÓN}

La filosofía latinoamericana actual no se reduce a historia de las ideas y a filosofía de la liberación, escuelas que han marcado una impronta en nuestra manera de hacer filosofía, pero que no dan cuenta de la riqueza de posibilidades que ofrece el pensamiento filosófico latinoamericano. Además de estas dos importantes vertientes de la filosofía de Nuestra América se encuentra, hoy en día, una buena producción académica en Filosofía amerindia, en Filosofía intercultural, en Hermenéutica analógica, en apropiación crítica de movimientos contemporáneos como la Arqueo-genealogía foucaultiana, estudios feministas o afro, o en tendencias emergentes como el Sentipensar ontológico, forma de ser de la ontología latinoamericana que lidera el Grupo de Investigación Tlamatinime en un trabajo de equipo entre varias universidades de América Latina: la Universidad Nacional de General Sarmiento, en Argentina, la Universidad Ricardo Palma, en Perú, y nuestra Universidad Santo Tomás con la Universidad Minuto de Dios, en Colombia.

La pregunta por el ser, clave en la filosofía clásica, y hasta hace poco ajena a la Filosofía Latinoamericana, ha sido asumida por los investigadores del grupo Tlamatinime, quienes se preguntan por la forma como los latinoamericanos pensamos el ser. En su indagación inicial por una posible ontología indígena se han preguntado por la concepción de ser o la comprensión ontológica que ofrece el pensamiento ancestral, ya sea en manuscritos de la Colonia que dan cuenta del pensamiento precolombino (como el caso de los nahuas y los estudios realizados por Miguel León Portilla, o el caso de pensamiento mestizo quechua en el manuscrito de Joan de Santa Cruz Pachacuti, realizado particularmente por Rodolfo Kusch, por ejemplo) o en trabajo de campo realizado con comunidades indígenas contemporáneas.

En esta línea de filosofías amerindias, se encuentra la filosofía andina, estudiada por Mario Mejía Huamán, por Gustavo Flores Quelopana, así como por Josef Estermann, entre otros. El interés de esta filosofía es rescatar esos saberes ancestrales propios de las comunidades 
andinas en su mayoría hablantes en lengua quechua y aimara. Estermann, por ejemplo, ha realizado un juicioso trabajo de campo, primero entre quechua-hablantes y luego entre aimara-hablantes, de donde ha propuesto su ya conocido texto de Filosofía andina desde la que explicita su concepción de racionalidad andina: la pachasofía, la runasofía, la ruwanasofía y la apusofía. Naturalmente, si se dan estos estudios sobre cosmología, antropología, ética y teología andinas, deviene la pregunta por la ontología propia de estos saberes propios del pensamiento amerindio de los Andes: ¿acaso en las sabidurías quechua y aimara se develan unos fundamentos ontológicos de ese su pensar?, ¿inclusive nos podemos preguntar por su concepción de ser de las cosas?, o sencillamente ¿en qué términos se pueden hallar los fundamentos ontológicos de la filosofía andina, para nuestro caso, según la propuesta que de ella hace Josef Estermann?

Con este problema de investigación no se buscará indagar la ontología de los incas, ni se considera de antemano que los pueblos indígenas de los Andes tengan toda una teoría elaborada sobre el problema del ser. El interés que acá nos motiva es investigar en la obra de Josef Estermann, y particularmente, en las dos versiones de su Filosofía andina, cuáles son los aportes a la ontología que se puedan ofrecer desde el pensamiento andino como una de las formas de la filosofía latinoamericana.

El pensamiento filosófico ha estado determinado por una tradición surgida y sistematizada en Europa. Esta filosofía se instauró en Latinoamérica con la llegada de los europeos quienes fijaron entre nuestras comunidades su modo de pensar y filosofar. Sin embargo, en América, desde mediados del siglo XIX, con Juan Bautista Alberdi, y de forma más actual, hacia la década de los años 70's del siglo XX debido a problemáticas sociales, culturales, políticas, económicas y ambientales, el pensar latinoamericano ha tendido a girar hacia un pensar propio, que le permita afrontar dichos problemas de forma alternativa, propia y situada en un contexto auténtico. De tal manera que unido a un interés político de descolonización y de reafirmación de lo latinoamericano, como clase y como identidad cultural, se han replanteado algunas de las cuestiones filosóficas, dando origen a postulados 
propios en términos de filosofía política (Dussel), de ética (Boff), y de antropología (Kusch), entre otras.

En este orden de ideas, en la búsqueda de un pensar propio, y de los fundamentos filosóficos de éste, resulta valioso para la constitución de la filosofía latinoamericana avanzar en investigaciones que den cuenta de la diversidad del pensar en América Latina, entre las que se halla hoy día la fundamentación de una ontología encontrada a veces implícita y otras explícita en nuestros saberes, discursos y prácticas cotidianas o académicas, con lo que podremos aportar a la profundización y avance del problema del ser, tanto como una manera de asumir nuestra identidad, así como de dialogar académicamente con la tradición de la filosofía clásica también llamada universal.

Si en verdad la filosofía, y con ella la ontología, son universales, no se comprendería cómo no pueden enriquecerse éstas, con los aportes de una ontología latinoamericana, que está buscando comprender el ser desde horizontes más amplios a los de la mera cosmovisión ratiocéntrica de la tradición europea. De ahí que se haga no sólo viable sino necesario avanzar en la investigación de los fundamentos ontológicos propios del pensamiento latinoamericano, dentro del cual hace su aporte la llamada filosofía andina.

Josef Estermann propone establecer una filosofía andina en la cual, incorporando elementos lingüísticos quechua y aimara, junto con vocablos griegos, se construyan categorías filosóficas del pensamiento andino. De esta manera se plantean cuatro dimensiones por donde transita este modo de filosofar: una cosmológica o pachasofía, en la cual se expresa qué es la filosofía como tal; una antropológica o runa/jaquisofía, en la que se asume una mirada al ser humano en relación con el mundo; una ética o ruwana/lurañasofía, que es asumida como una forma de 'estar bien', sustentada en el trabajo; finalmente una apu/tatasofía, en la que se describe la relación con lo espiritual, una explicitación de lo que en el mundo andino es considerado como divino y las formas de relacionarse los hombres/mujeres andinos con tal dimensión. 
Empero, en las categorías mencionadas no se hace una orientada al ser directamente, que dé pie a una ontología. Sin embargo, Estermann plantea unos aspectos en los que el componente ontológico parece mostrarse: el principal es el principio de relacionalidad, el cual se hace evidente en todos los campos de la filosofía andina; otro, es el concepto de pacha como totalidad, en el que convergen y sustentan un sinfín de relaciones que le dan cuerpo y esencia a esa totalidad. Los aspectos mencionados permiten buscar el principio de ser y el fundamento.

Teniendo en cuenta lo anterior, se expone como tesis que la filosofía andina de Josef Estermann contiene unos fundamentos ontológicos implícitos en las categorías del pensamiento andino. Al preguntarse por el sentido profundo de pacha se evidencia que resulta simplista la traducción por madre-tierra: para el pensamiento andino, en la tradición quechua-aimara, parece ser que pacha es un principio fundamental de todo lo que es, sujeto de la relacionalidad entre todos los elementos que la constituyen, a saber: tierra, donde estamos; lo que hay sobre la tierra, que incluye ciertas divinidades que nos acompañan; lo que hay debajo de la tierra, y que vendrá a ser morada de esa otra forma de vida venidera; pasado y futuro que están íntimamente relacionados en el presente; etcétera. En pacha cabe todo lo que hay, sujeta todo lo que se interrelaciona, posibilita toda esperanza, incluida la salvación, y sustenta nuestro estar en el mundo, casa a nuestro cuidado. En este contexto, a pesar de que el pensamiento andino no centre su apuesta ontológica con el término ser, es evidente que la pachasofía, como la llama Estermann, constituya esa disciplina que la filosofía tradicional conoce como ontología.

El trabajo de investigación requiere para su óptimo desarrollo una división capitular que permite encontrar el sentido del problema de los fundamentos ontológicos en la filosofía andina de Josef Estermann. En el primer capítulo se desarrolla el estado de la cuestión como una reconstrucción histórica de los estudios y avances de la ontología en América Latina y como una descripción de las categorías ontológicas que han surgido en nuestro continente. Cronológicamente se despliega la forma de comprender el ser en nuestro continente, dejando entrever, más que la necesidad de responder con voz propia la pregunta 
por el ser, la inconmensurabilidad del ser, las diferentes formas que tiene de comprenderse y diferentes elementos compartidos constantemente en la experiencia del ser.

En el segundo capítulo se propone una descripción fenomenológica sobre el fenómeno de lo andino que da apertura a conocer algunos aspectos propios de Josef Estermann que permiten encontrar su interés por el mundo andino y su inquietud por 'rescatar' una filosofía andina abierta a la filosofía universal. En este mismo capítulo se exponen los argumentos que sustentan la propuesta ontológica en Josef Estermann. Se parte de las categorías de relacionalidad andina, de la expresión pacha y del vocablo chakana como fuentes conceptuales que posibilitan encontrar el sentido de ser en la filosofía andina de Estermann. Este capítulo ofrece algunas categorías conceptuales que permiten definir el ser en diálogo con la tradición filosófica; así, se desarrollan la categoría de relacionalidad, totalidad del ser y comprensión del sentido de ser en el ser. Además presenta los fundamentos ontológicos en tres condiciones distintas, pero relacionadas casi que necesariamente, como en una trinidad andina.

El capítulo final está destinado a la presentación de las conclusiones surgidas a lo largo de la investigación, con las cuales se pretende aportar más preguntas a la cuestión ontológica en el pensamiento latinoamericano y del mismo modo constituirse como un referente para posteriores investigaciones tanto en lo relacionado con la filosofía latinoamericana y con el pensamiento andino, como con la ontología y el pensar. 


\section{ONTOLOGÍA EN AMÉRICA LATINA}

Encontrar elementos ontológicos en la filosofía latinoamericana requiere hacer un registro detallado de diferentes formas de tratar el ser o lo-que-es, registro que puede encontrase históricamente en la recepción de las ideas metafísicas que llegaron con la escolástica y su posterior desarrollo en formas, que si bien llevan implícito el elemento latinoamericano, no tomaron mucha distancia de la forma de comprender el ser desde la filosofía de corte tradicional; pues en muchos casos se trataba de comentarios a las obras de Santo Tomás en los cuales se mantienen estrechos vínculos con la teología.

En la misma línea de los avances en metafísica y ontología se encuentran los aportes de Marín de Alcázar con sus distinciones en la identidad de los entes; esto supone un serio trabajo racional e intelectual en lo concerniente a revisiones y aportes a los planteamientos del Aquinate. En el mismo sentido se encuentran las disertaciones de José Eguiera y Eguren acerca de las esencias físicas y metafísicas de Dios, así como los atributos y las relaciones de Dios (Cepeda, 2009: 57), a lo anterior se suman las contribuciones de Andrés de Guevara y Bazoazábal en las que integra propuestas de la modernidad como «las causas ocasionales de algunos racionalistas, como Descartes y Malebranche» (Beuchot en Cepeda, 2009: 58), con minuciosos análisis sobre la esencia, la existencia y el ente.

Sin embargo, gracias a los aportes de las escuelas filosóficas de Europa (principalmente), es posible encontrar y comprender, y hasta desarrollar, propuestas alternativas para definir el ser desde nuestro contexto latinoamericano. En América latina han surgido propuestas de categorías ontológicas, situadas en un contexto cultural y territorial, que amplían el horizonte cuando se requiere retribuir a la filosofía universal y a la ontología definiendo el ser. Tenemos entonces siete aproximaciones en el campo de la ontología en Latinoamérica que aportan elementos de análisis para encontrar fundamentos ontológicos en la Filosofía andina de Josef Estermann. 
En este sentido, se abordan cronológicamente, para dar un panorama de la ontología de América latina la filosofía de estar, planteada por Rodolfo Kusch; la metafísica desde América Latina, postulada por Germán Marquínez; la teoría de la Habencia, propuesta por el mexicano Germán Basave; La ontología simbólica, una propuesta hermenéutica desde Mauricio Beuchot; las categorías quechuas de ser y existencia, elaboradas por el filósofo peruano Mario Mejía Huamán; una mirada antropológica del Alemán Wolfgang Kapfhamer sobre la ontología animista del pueblo Satere Mawe del Amazonas, finalmente las aproximaciones ontológicas basadas en el sentipensar, una propuesta trabajada por el profesor Juan Cepeda H.

\subsection{La ontología en el estar}

En la búsqueda de concepciones ontológicas en América Latina no es posible dejar de tener en cuenta la propuesta del filósofo argentino Rodolfo Kusch, quien, a partir de sus trabajos de antropología filosófica, aplicados al estudio de las culturas alto-andinas, logró desentrañar del pensamiento andino y popular latinoamericano algunas bases sólidas del pensar filosófico, donde se destacan la profundidad de sus análisis y el encuentro de un lugar diferente al europeo para plantear y resolver preguntas fundamentales para la filosofía.

Así, encontramos en el pensar latinoamericano la categoría ontológica del estar, desde una mirada en la que lo íntimo del hombre, no como individuo, sino como especie, se revela para encontrar el fundamento de la existencia en una realidad concreta, distante y distinta del ideal dinámico del ser, presente en el pensar europeo; de modo que «el mundo estático se inmoviliza en el esquema mágico que se ha hecho de la realidad, mientras que el dinámico confía su acción a un escamoteo de la realidad logrado a base de ciencia» (Kusch, 1963: 22); en otras palabras, el estar se define como una condición única de hacer

parte de este mundo y aceptarse en él como centro inmóvil que no puede escapar de los elementos de la naturaleza ni crear sustitutos para alejarse de ella misma. 
De la Mano de América Profunda (Kusch, 2000), es preciso examinar la categoría del estar a partir de los encuentros del autor con personas campesinas e indígenas del norte de argentina. El indígena latinoamericano al que hace referencia la obra, vive en una angustia existenciaria que no nace de la incertidumbre del mañana o del qué ser, sino por el contrario, surge de la certeza de la ira de dios, del presente, del caos y del a dónde se está arrojado; a un mundo donde han de convivir una dualidad de elementos (al parecer) antagónicos como lo diurno y lo nocturno, el frio y el calor, lo femenino y lo masculino, la abundancia, la cosecha y la siembra.

Tales dualidades elementales se presentan con un ritmo que hay que descubrir porque «el mundo es el caos y debe ser sometido al orden divino, que es el orden del Pachayachachic o sea el calendario» (Kusch, 2000: 84); con lo anterior, el estar en el mundo tiene como base para la estaticidad misma de la condición de estar la certeza de lo móvil que se da al interior del hombre/mujer andino, cuyo centro de este movimiento rítmico, que es el hombre/mujer andino, queda como una 'víctima' del mundo, sujeto tanto al orden del 'maestro' Viracocha como al caos del mundo.

El estar como categoría ontológica parte de una angustia existenciaria fundamentada en la búsqueda constante de las condiciones vitales para poder existir; pues se está arrojado en medio de los elementos de la naturaleza de los cuales carece de dominio. El hombre latinoamericano podrá moverse por todo el mundo, e intentar escapar a tal 'destino', pero su situación siempre estará sujeta tales fuerzas.

La forma de comprender este destino no se da en la exterioridad del hombre sino en la interioridad, tal como los huancaquilli o ascetas que vivían en soledad en las montañas «para que llamaran y alcansaran y conocieran que dónde estaua el Hazedor del cielo y la tierra (sic.)» (Kusch, 2000: 86), además intentaban controlar el cosmos vía introspección, por medio del ayuno o abstención de las cosas externas con lo que se adquiría una 'conciencia' del estar como Viracocha, «como si Viracocha no solo pueda ser conocido 
mediante una vía interior, sino que, dada su verdadera existencia, él es quien toma al creyente como un ensueño» (Kusch, 2000: 89), es decir, que en la inmanencia del que está se encuentra el dios como fuerza creadora y vital, capaz de ordenar el mundo sin desplazarse del mismo.

Aquí se comienzan a comprender las características del estar dadas en la angustia ante la certeza de la dualidad de la realidad concreta, la conjuración del mundo y la búsqueda del sentido del estar como Viracocha en la interioridad. La forma en que se sitúa el hombre andino en su estar se asume como un sujeto pasivo e inmóvil ante el mundo del cual precisa defenderse, al menos de la ira de dios representada en las fuerzas de la naturaleza; esta condición se refleja en la connotación del verbo quechua cay que se utiliza en el castellano como ser y estar, pero referido más precisamente a la condición de estar, ya que «esta lengua no tiene conjugación propiamente dicha, como abstracción del movimiento, sino que ésta se hace adjudicando cualidades a un sustantivo» (Kusch, 2000: 108), en otras palabras, en la estructura gramatical quechua los verbos son condiciones de estar de un sujeto pasivo «el sujeto no se altera en la acción sino que cambia de tonalidad o de colorido según la cualidad que lo tiña» (Kusch, 2000: 108).

La condición del estar aparece en una cultura donde se asume un mundo que afecta todo lo que hay en él y donde lo afectado solo se permite contemplar 'pasivamente' «porque todo su movimiento es interno y se rige por el compromiso con el ámbito» (Kusch, 2000: 116), así, contemplando, se está frente al frio, frente al día, frente a la cosecha, frente a las diversas situaciones que arriba se han mencionado. El sujeto que está reconoce su mero estar como una parte más de esa naturaleza que lo aterra, pero de la que no puede escapar sino conjurarla.

El ser de la cultura occidental, por su lado, pone el énfasis en el sujeto de la acción, no como un sujeto pasivo que está ahí, sino como un sujeto activo 
que afecta el mundo y lo modifica, y es la enajenación a través de la acción [...] o sea que es una solución que crea hacia afuera, como pura exterioridad, como invasión del mundo o como agresión del mismo, y ante todo, como creación de un nuevo mundo (Kusch, 2000: 112).

Estar y ser se encuentran opuestos en Kusch, su origen se halla en la concepción del mundo que se ha hecho; la primera, del estar, se hace desde una concepción femenina y agraria en lo que lo que es así comienza y termina por determinar el rumbo, tanto del hombre, como de las plantas y todo lo que esté en. De otro lado, la concepción del ser se da en una cultura que rechaza lo agrario y pasivo; donde predomina la ciudad y la suplantación de la naturaleza indomable por objetos que se pueden transformar, como un sucedáneo de la transformación de la misma naturaleza. En esta concepción, el hombre se asume como un individuo inestable ante las vicisitudes de la naturaleza y se rehúsa a dejarse absorber por esta, dándose luego a crear imitaciones de la naturaleza para encontrar su seguridad en lo exterior y por él creado y no en lo interior como él creado.

El estar requiere mantener 'vivo' el pensamiento mágico de una realidad, un pensamiento que no se puede trasladar ni cambiar, (Kusch, 2000: 117) tal como sí se hace con las teorías en las que sustenta el ser desde la filosofía europea. La concepción mágica del mundo, que ha de ser conjurada solo se puede hacer por medio de la ritualidad y la espiritualidad, vinculadas estas últimas a una fuerte emocionalidad que en igual medida dota de sentido vital y real el estar en el mundo.

Para el filósofo argentino, lo que es requiere de un estar previo para poder darse su ser; tanto los elementos constitutivos del paisaje alto-andino, como las fuerzas de la naturaleza, solo están ahí, no por que algún humano les haya dado el ser, sino porque en la misma dinámica de caos/orden del mundo aparecen y están dispuestas para ser conjuradas luego.

El mundo europeo del ser suele ser un mundo donde la naturaleza es enfrentada y suplantada por objetos, como las mismas ciudades; al interior de las murallas se construyen 
objetos y utensilios que permiten al hombre tomar distancia de ese mundo animal o natural que le crea terror «porque delega en él [el utensilio] la misión de modificar y aprovechar al medio» (Kusch, 2000: 148). Al tener esta posibilidad de modificar la naturaleza (aparentemente), se convierte en un creador de otro mundo, de una naturaleza que depende ahora del hombre; «los objetos creados reemplazan a la naturaleza» (Kusch, 2000: 149) para adaptar la vida a las necesidades del hombre.

Con esta actitud de ser se busca asegurar el alimento y la supervivencia, la misma preocupación del estar, pero arrebatando el control a las fuerzas de la naturales, siendo el controlador. De ahí que todo lo creado con esta actitud de convertir el mundo en objeto le brinde esa categoría de ser, pues se le conoce desde su origen como algo 'atropo-creado', en pocas palabras, el ser y los objetos se encuentran en una misma dimensión cultural.

Hay una distinción entre lo que se ha dado en llamar prehistoria e historia, basada en la propiedad sobre el mundo que hace el hombre como su creador; en lo que se dice prehistoria no hay un propósito de adueñarse del medio, solo se está en la naturaleza como hijo de esta y como especie humana, «por ello no fue incorporada a la historia, ya que esta es, en cambio, la que relata los hechos producidos por los creadores del mundo moderno» (Kusch, 2000: 153).

Lo anterior da cuenta de dos formas de entender la historia, una primera desde el estar o gran historia y otra desde la pretensión del ser o pequeña historia, que no es más que una porción de la realidad, re-creada por una élite acorralada por una ciudad y una cultura que impone la escisión entre lo que se considera bueno, que está en la ciudad, y lo que es malo que se sitúa afuera de la ciudad, como residuo del ser. De modo que «en el sector residual se juegan las verdades del estar, en el plano de la planta que crece, y en la élite las verdades inestables del ser, en el plano del objeto acabado» (Kusch, 2000: 157), y es que tal instabilidad del ser, no puede ser conjurada, pues depende de la voluntad y competencia de los habitantes de la ciudad, que son creadores de objetos, opuesto a la estabilidad de los ritmos del mundo y de su caos. 
En este punto, se comprende que la bandera del estar se encuentra afuera de la ciudad, lejos de sus códigos de pulcritud y raciocinio, en la anti-ciudad, donde estaban los miedos originales encarnados en el rayo, el relámpago y el trueno y, detrás la ira de dios. El estar se asume como una convivencia con el temor y la naturaleza. En una cultura del estar «vivir, consiste entonces, en mantener el equilibrio entre el orden y el caos, que son las causas de la transitoriedad de todas la cosas» (Kusch, 2000: 199) antes que una eliminación de estas y una suplantación por objetos creados. El estar se vincula con lo interno y natural del hombre, ya sea como especie o individuo; se encuentra tanto en los creadores de objetos, que lo hacen para huir de su condición natural y temerosa, como en los elementos externos a la ciudad. Tal como esta se encuentra rodeada, más allá de sus muralla, por un paisaje agreste donde vive la ira de dios, el ser está rodeado de un entorno del estar, «se diría que estamos sitiados por el mero estar como forma de vida» (Kusch, 2000: 193) lo cual propicia un proceso de fagocitación del ser por el estar.

El estar se presenta como una categoría ontológica que se despliega en una ámbito de lo popular e indígena donde la pretensión por superar la naturaleza se deja de lado y se asume una conciencia de estar en el mundo, como un destino del cual no es posible escapar. Este estar se caracteriza por una conciencia mágica de un mundo que no puede asirse con las manos ni mucho menos controlar; entonces debe conjurarse para revelar esa conciencia de ser parte central del cosmos y caos que marcan el ritmo de la vida. De acuerdo a lo anterior el estar supone una actitud existenciaria soportada en la angustia de lo estático y que eso estático son el caos y el orden siempre juntos.

\subsection{La metafísica desde Latinoamérica}

La metafísica desde Latinoamérica es una propuesta para la filosofía latinoamericana que plantea Germán Marquínez en vista de la necesidad en el continente de pensarse 
situadamente en una realidad signada por el subdesarrollo y la dependencia provocada por el ideal europeo que llega a nuestro continente en cuando el

Yo europeo moderno se convierte en un Yo conquisto, Yo-domino, Yo-decido, Yopienso [y] Los demás son entes conquistados, dominados, colonizados, pensados, es decir, oprimidos. [...] América Latina es un continente ontológicamente oprimido por una 'voluntad de poder' ejercida en la totalidad mundial por Europa (Marquínez. 1977: 69)

La metafísica desde Latinoamérica pretende alinearse con las propuestas de liberación que en los años setentas del siglo XX hacían correría. Marquínez Argote plantea, mediado por la filosofía de la liberación, establecer una metafísica latinoamericana que se ocupe de los problemas del subcontinente.

La postura de la metafísica desde Latinoamérica busca conectarse directamente con la realidad que atraviesa el continente; esta, a su vez se levanta en crítica contra posturas tradicionales de la filosofía en Latinoamérica y de la misma metafísica que se ha encargado de repetir discursos extranjeros, que si bien podrían decir algo sobre el continente, no están situados en el contexto histórico y espacial latinoamericano.

La metafísica descrita por Marquínez tiene su origen en el mismo hombre; asegura que esta solo le acontece al hombre por lo que solo el pensamiento racional abre el entorno real a un mundo, es decir el hombre en su dimensión metafísico se abre al mundo se sitúa como centro del mismo; «instalado entre cosas, el hombre ocupa un determinado lugar entre ellas. Tal ubicación es, por supuesto, céntrica.» (Marquínez, 1977: 32). Lo anterior sitúa a la metafísica latinoamericana en un centro situado en la realidad continental y temporal en la que se vive, un entorno que «además de afectarnos y moldearnos profundamente, constituyen nuestras posibilidades de vida» (Marquínez, 1977: 33) las cuales repercuten en la idea de realidad y de mundo sobre las que se desenvuelve el pensamiento de Marquínez respecto a la metafísica. 
Para esta propuesta metafísica la realidad tiene primacía sobre el ser, perspectiva retomada de Zubiri para quien el ser se funda en la realidad. Tal mirada sobre la realidad deja en un segundo lugar «una ontología del Ser Universal Univoco, propia de filósofos al servicio de la dominación o de catedráticos célibes de sospecha y espejos de inocencia (la inocencia del ser» (Marquínez, 1977: 92) en las que la idea que se tiene del ser es de un ser autosuficiente idéntico a sí mismo y que no deja espacio para un 'lo otro', lo cual adopta una posición totalizadora. La realidad latinoamericana se visualiza, pues, como ese otro que da un qué decir, qué sentir y qué pensar autentico.

Desde esta realidad se propone «la ruptura definitiva y sin ambigüedades con la ontología, [se afirma] la necesidad de una metafísica de la realidad (de "lo otro") y una metafísica de la alteridad (de "el Otro")» (Marquínez, 1977: 93). En otras palabras no se plantea un ontología latinoamericana porque recaería en la exaltación del ser sin contemplar donde este se presenta; el planteamiento es de una metafísica que explora en la realidad concreta misma las formas de ser, estar o haber que pueden surgir, pero tomando distancia de la totalización que supone la univocidad de lo que significa ser en la tradición filosófica.

Empero, la metafísica desde Latinoamérica no procura hacer una oposición a la ontología, lo que plantea es una crítica a la forma en que se ha asumido en el continente. La primera crítica que hace es al idealismo con el que la modernidad viste al ser y que lo remite al pensamiento subjetivo donde «solo a partir de la idea es comprensible la realidad natural y humana [...] la idea es el principio y fin de todas las cosas; lo engloba todo, es el todo: totalidad dialécticamente totalizada y cerrada sobre sí misma» (Marquinez, 1977: 95).

El problema con la ontología así asumida es que el filósofo ideísta va a comprender una realidad que no es tal, sino siempre ajustada a sus conceptos e ideas de forma lógica; «usa y abusa de la lógica de los principios: especula, combina verdades hasta conseguir el “sistema" que contenga todas las verdadera ideas en las cosas» (Marquínez, 1977: 97). Una ontología así pensada, incompatible con el propósito de Marquinez, en el cual la realidad 
marca el 'ritmo' del ser y en la que lo 'concreto' es lo verdadero antes que las ideas, va a tener como consecuencias el desconocimiento de la realidad y la sobre-validación del concepto hecho desde el sujeto que se crea un ethos de conquistador donde la voluntad hace la realidad

La realidad es la base sobre la que se fundamenta la metafísica desde Latinoamérica, entendida como lo que le es propio de lo que hay en el mundo, del mismo modo esta puede ser hecha por el hombre. Realidad no consiste únicamente en el conjunto de elementos constitutivos del entorno sino que se enmarca dentro del horizonte donde se mueve la inteligencia del hombre, es decir lo que adquiere un sentido para él, pero conservando lo propio de las cosas que no son 'de mi' sino de suyo. Por un lado el hombre reconoce la realidad en las cosas, sin embargo tales características propias no son constitutivas solo por voluntad e inteligencia del hombre sino que son realidades de las cosas en sí.

Así, «aunque la verdad (como carácter real de una cosa) se da ante la inteligencia, son las cosas las que dan verdad o, utilizando un neologismo zubiriano, son las cosas las que verdadean ante la inteligencia»(Marquínez, 1977: 126), cual si las propiedades reales antecedieran el ser de las cosas y la nominación lógica que puede hacer el hombre con su inteligencia.

La realidad se presenta de dos formas, una natural que es inherente a las cosas y otra por apropiación, como adquirida en un plano ideal y conceptual, «luego algo puede ser 'de suyo' de muchas maneras: el color de la piel lo es por naturaleza, la ciencia o virtud por apropiación» (Marquínez, 1977: 121), dicho concepto va más allá de lo que ofrecen las cosas en el sentido que lo que es 'de suyo' o propio de las cosas también puede ser creado por la mediación del hombre con su entorno.

Si bien «las cosas reales tienen esencia [y] el "qué" esencial se refiere formalmente solo a un mínimo de notas: aquellas que no pueden faltarle a una cosa sin que deje de ser lo que es» no se puede confundir lo real de las cosas con las cosas en sí, la realidad subyace a la 
substancia y trasciende el plano ontológico dado que solo en la realidad es que las cosas pueden ser y tener su características propias 'de suyo' y esas características son su realidad.

Volcando la mirada hacia Latinoamérica, la propuesta metafísica de Marquínez se fundamenta no en el olvido del ser mencionado por Heidegger (1998) sino «en el olvido de nuestra realitas por obra del colonizaje. La realidad del hombre dentro de sistemas opresores es la destitución de la realidad del hombre como exterioridad» (Marquínez, 1977: 123); en este sentido no puede haber una búsqueda del ser desconociendo la realidad latinoamericana, como algo por descubrir en medio del mito ontologizador de occidente; «la realidad, como haber, se relaciona con lo nuestro originario, con el subsuelo limpio de maleza ontológica opresora» (Marquínez, 1977: 123) de la cual hay que liberarse de forma que se tengan en cuenta «la voz histórica del pobre, del pueblo [estableciendo] compromiso con esa palabra» (Marquínez, 1977: 123), retornando al señalar las cosas como si carecieran de nombre y realizarlas de nuevo.

La consolidación de la metafísica desde latinoamericana se debe realizar partiendo de las características de la realidad de las cosas en términos tomistas de unidad, verdad y bondad. Tales características que han sido definidas desde la unidad totalizadora de Europa se subvierten de orden para dar cuenta del piso latinoamericano sobre el que se edifica la propuesta metafísica de Marquínez.

En primer lugar la unidad debe provenir de las propiedades mismas de 'lo latinoamericano' y hacer a un lado la «unidad que hemos vivido [que] nunca ha sido nuestra» (Marquínez, 1977: 129) y que ha creado ciertas ilusiones de independencias políticas sumiendo al continente en otro tipo de dependencias más hondas que limitan el surgir de la soberanía. En la misma dirección, la verdad, también impuesta, se ha basado en un deber ser «para coincidir y adecuarnos a las exigencias semántico-pragmáticas del discurso unívoco de la Totalidad» (Marquínez, 1977: 129), esta se ha construido de espaldas a la realidad provocando vacíos en la construcción de identidad, no solo política, sino de ser; «no hemos 
sido auténticos porque hemos vivido verdades ajenas y formales dictadas por el centro» (Marquínez, 1977: 129).

Finalmente, en ausencia de unidad y verdad 'de suyo' latinoamericanas, la bondad que mueve la voluntad del hombre se encuentra velada bajo la consigna de que «el ser latinoamericano es bárbaro y que necesita del soplo de una cultura superior para nacer al espíritu, a la verdad y al bien» (Marquínez, 1977: 129) lo cual ofrece una apertura para el encuentro de una nueva voluntad signada por los caracteres propios de la realidad latinoamericana identificada consigo misma y formulada por las voces de 'los otros' que no son centro como sustento para el desarrollo de una metafísica latinoamericana.

\subsection{La ontología en la habencia}

El filósofo Mexicano Agustín Basave Fernández hace su aporte a la ontología latinoamericana con su propuesta de la Teoría de la Habencia, una teoría metafísica novedosa que pretende darle una mirada diferente a la pregunta por el principio de todo lo que hay; se desenfoca de la pregunta por el ser porque «no hay ninguna "pregunta por el ser, como totalidad", [...] porque el ser no es una cosa sustantivada ni existe fuera de los entes» (Basave, 1982: 29), sino que busca encontrar eso que trasciende al ser, una realidad que lo fundamenta en su facultad misma de haber, en la cual el ser se actualiza o se hace presente en concreto.

La habencia se entiende como un campo concreto que está antes del ser y que abarca más allá de los entes reales. Todo cuanto hay, tenga o no existencia concreta, aparece en el campo de la habencia superando inclusive la dimensión de la temporalidad; tal que «lo que es [presente], lo que ha sido [pasado perfecto] y lo que será [futuro simple] es lo que hay. El ser es la presentidad situacional, respectiva del “hay”»(Basave, 1982: 26) El ser, como aparición presente lo hace dentro lo la habencia, como siendo parte de esta. 
La habencia surge de la pregunta por el principio de todo, «pregunta [que] parte del supuesto que hay un todo» (Basave, 1982: 29) y que orienta la mirada ontológica no tanto por el ser sino por lo que hay entorno al ser. Esta pregunta se formula sobre una realidad que ya está preconcebida, como que ya la hay y de la cual busca hacerse consciente, « ¿si no estuviese instalado en la realidad, cómo podría preguntar por ella? Algo sabe de la habencia si pregunta por ella» (Basave, 1982: 29). En la habencia el hombre se sitúa como una realidad habiente y presente, que busca comprenderse como un ente que es en ella; la pregunta por lo que hay también es un pregunta por su propio haber.

«La habencia es real, independientemente del conocimiento que de ella tenemos. Inmerso en el horizonte de todo lo que hay, el hombre se encuentra en la habencia como en su casa» (Basave, 1982: 31) y es facultad de su inteligencia poner la totalidad de todo lo que hay a su alcance, tal como lo propone Heidegger al afirmar que el «"ser ahí" se comprende siempre a sí mismo partiendo de su existencia, de una posibilidad de ser él mismo o no él mismo. Estas posibilidades, o las ha elegido el "ser ahí" mismo, o ésta ha caído en ellas o crecido en cada paso ya con ellas» (Heidegger, 1998: 22). Es el hombre que se pregunta por comprender, ya sea lo que es o su habencia, siempre está situado en su existencia concreta como llamado a saberse parte de una realidad que le aparece ante los ojos.

La realidad, desde la cual parte la pregunta por la habencia, no es superior al espectro de la habencia, el horizonte de la realidad se hace patente como una de las posibilidades que presenta la habencia, lo que va a ser posible y no concreto no se toma en cuenta como realidad, pero sí como algo que hay inserto en el horizonte habencial donde está «lo concreto y lo abstracto, los entes reales y las ficciones, los universales y los valores, la realidad como sentido y el continuo de la realidad [...] no es un horizonte ontológico sustantivado sino lo que hay en las cosas que hay, las realidades y las posibilidades en la medida en que las hay, con todas sus articulaciones y confluencias» (Basave, 1982: 32). Totalidad que trasciende el ser mismo y se presenta ante el hombre conscientemente. 
La habencia es trascendente, incluso al hombre que cae en cuenta de ella y la interpela, porque en la habencia los entes que son, solo existen como acontecimientos limitados y conscientes de ello, «si conozco lo que está más allá del límite, ese algo es el horizonte de la habencia» (Basave, 1982: 34), lo que marca una totalidad inabarcable pero finita de modo que «el horizonte de la habencia comprende todos los horizontes parciales de cada cual y el horizonte del mundo» (Basave, 1982: 35).

La condición de haber de un ente entra a mirarse detenidamente partiendo de lo que define tal circunstancia o, en términos de Basave, lo que hay en el haber y lo hace fundamental en el planteamiento de la propuesta de una nueva metafísica desde Latinoamérica; lo anterior referencia a las múltiples connotaciones que dan cuenta de las posibilidades que, como verbo, tiene de decir de algo, por ejemplo

a) hallarse o existir real o figuradamente (hay hombres sin humildad...), b) denota el transcurso del tiempo (...ha dos semanas), c) verificarse, efectuarse (ayer hubo labores en la universidad), $d$ ) verbo auxiliar que sirve para conjugar otros verbos en los tiempos compuestos (...tú habras aprendido), e) acaecer, ocurrir, sobrevenir ( $h u b o$ un accidente), $[\ldots] j$ ) estar realmente en una parte (haber seiscientas personas en una conferencia) (Basave, 1982: 39-40).

Basave recurre a sustantivar la condición de lo que hay, sustentado en «la necesidad de forjar el sustantivo habencia -cuya connotación que le quiero dar se acerca a la expresión castellana lo habido y por haber- para indicar la totalidad de todo cuanto hay» (Basave, 1982: 40) como una característica esencial que tiene todo lo que hay.

Al dar la mirada metafísica al haber, se sostiene que «es un antecedente del ser en uno de sus elementos metafísicos: la esencia. El haber del hay algo, antes que decir que es, sobrepasa a toda reflexión filosófica» (Basave, 1982: 40) porque lo primero que hay que decir del ser del ente es que ya hay; que ocupa una habencia, así «afirmemos o neguemos la esencia o la existencia de tal o cual ente, queda siempre la habencia» (Basave, 1982: 40) 
porque en ella podemos «negar, afirmar, atribuir, descartar, demostrar, dudar, creer, evidenciar...» (Basave, 1982: 40). La habencia se expresa metafísicamente porque es primera, antes (incluso) de la posibilidad.

La habencia va más allá del ser, de la esencia. Los entes que tienen esencia, existencia y concepto solo se hallan y habitan en la habencia concreta y total; al decir que algo es, loque-es, lo hay primero y después permite que lo-que-es se pueda definir en la habencia; Basave hace notar en su nueva metafísica que:

El a priori originario es el hay que me permite captar el ente. Y en el ente aprehendo la esencia y la existencia. La experiencia de ser es una experiencia del ser de los entes. Lo omnipresente, lo envolvente (...) no es el ser de los entes sino la habencia, todo lo habido y por haber desde el hay » (Basave, 1982: 41).

O sea que lo que es real es la habencia y el ser es lo que permite interpretarlo desde lo humano, el ser es solo «una interpretación de su aspecto [el de la habencia] entitativo» (Basave, 1982: 41) y una actualidad de la habencia de carácter respectivo, es decir que debe ser referido a algo.

Desde la perspectiva de la habencia se define el estar como «una cierta permanencia y estabilidad en este o aquel lugar, situación, condición o modo actual de ser» (Basave, 1982: 42) el estar y su condición de estabilidad se hayan dentro del horizonte de la habencia, pues dentro de su variadas connotaciones (verbo reflexivo, obligarse, tener una cualidad adjetiva o disposición) no plantea una trascendencia metafísica que, siquiera, lo priorice como un(a) constante, difiriendo de la relevancia ontológica que le imprime Kusch como la permanencia de la condición del hombre.

En la habencia, el estar se reduce a un instante de esa forma conceptual de definir el ente. Por ejemplo cuando se dice: 
«ioh, hermoso cielo!, aludimos a una relación atemporal fuera del tiempo. En cambio cuando decimos el cielo está hermoso, nos referimos a la duración de la nota en el sujeto. (...) Ser indica la pura relación atributiva, la nota definitoria, la nota pensada como no susceptible de cambio; estar significa la duración, la nota vista como mutable» (Basave, 1982: 42)

También en la habencia, la condición de estar se presenta como un atributo no esencial del ente, sino como una condición afectada por la temporalidad y la duración del fenómeno, «los cuerpos están en la habencia, pero no son la habencia. El "estar" lo pone el cuerpo. El “en” lo pone la habencia» (Basave, 1982: 42), el momento o el lugar en el que se está o en lo que tal "estar" puede haberse es la habencia misma.

La teoría metafísica de la habencia reposa sobre una postura ontológica en la que la

existencia, la intuición del ser existencial, tiene la primacía sobre la esencia, como el acto precede a la potencia. Pero esto no significa que se destruyan o se supriman las esencias. Todo lo contrario, la existencia implica las esencias o naturalezas y con ello salva la inteligibilidad (Basave, 1957: 40).

La habencia está relacionada íntimamente con la existencia en concreto, esta última es componente fundamental en la teoría de la habencia, sustenta la necesidad de la concreción del mundo y de la realidad que aparece ante los ojos, la existencia de los entes es lo que hace que el ser sea inteligible, que su habencia sea demostrada simplemente como presencia que está en la realidad. Por su lado la esencia que refleja lo que hay de inteligible en un ser (Basave, 1957: 42) está incorporada en una comunión con lo real para que este sea presente y se haga una conciencia de la misma.

La habencia como categoría metafísica parte de cinco principios fundamentales, todos primordiales, desde los cuales se busca dar sentido metafísico. De este modo el profesor Basave revela la presencia como el primer principio de la habencia: 
Uno de los principios metafísicos de la habencia, intuibles con la misma habencia e inderivalbles de cualquier otro principio - de otra suerte no sería primer principio -es el principio metafísico de la metafísica de la presencia: todo cuanto hay está de algún modo presente (Basave, 1982: 93)

Un segundo principio es el del contexto que de acuerdo a Basave se refiere a un entramado que está en la habencia. La habencia es contextual porque todo en ella está enlazado hilado, tramado; dice el Mexicano «puedo desconocer, en detalle, el orden de la composición pero no desconozco que hay una composición» (Basave, 1982: 96). De ahí que todo lo que es real en lo habiente precisa de un entorno -exterior- en el cual se da el ser, un contorno - que delimita a dicho ser en lo que es- y un dintorno, que es eso que hay en lo que es propio del ser en su interior cuando se presenta. Estos elementos sustentan el entramado de lo que hay en la habencia, así todo cuanto hay se ofrece e marco lógico existencial.

El sentido es el tercer principio de la habencia y se explica como una motivación que lleva al hombre a conocer lo que hay; en la habencia el sentido es lo que permite al hombre querer encontrarse en la realidad de la habencia y definirla

Un impulso de explicarlo, todo nos acompaña siempre. Y queremos explicar lo que hay en el horizonte de la habencia no solamente por el afán de dominio -como quieren hacernos cree Heidegger y Klages- sino por amor y veneración al maravilloso misterio de la habencia y su fundamento (Basave, 1982: 97).

Tal búsqueda de significado se revela como una aspiración del hombre que es imprescindible para vivir, este principio busca trascender la temporalidad de los entes y aferrarse a lo permanente, el sentido es el aspecto pensable de los entes, es decir lo que la realidad concreta de algo que hay queda remanente en la mente del hombre y de llena de significado. Se pude decir que el sentido encuentra la intencionalidad del ente en la habencia. 
La sintaxis es el cuarto principio; mantiene relación con la coordinación de las palabras que se da en el aspecto linguiístico de la lógica, la sintaxis muestra la coordinación de todo lo habiente y la articulación en función de algo, «la sintaxis como primer principio metafísico de la habencia no va al lenguaje, va lo que hay coordinado y coordinándose» (Basave, 1982: 101) en el mundo concreto; es un principio extralingüístico que relaciona en un previo, en momento y posterior los entes que participan de la habencia.

La participación es el quinto principio de la habencia; aquello que mantiene los entes en la habencia, pero no siendo partes de un ser fragmentado que fundamenta la habencia, sino como entes que, sin ser el ser, participan de la existencia que este les provee.

No es que les robemos a Dios una parte, es que por la creación participamos de sus dones $[\ldots]$ hay una participación de la existencia, y en la existencia que suscita determinadas y limitadas potencias de existir [...] el participado es acto puro e infinito de existencia (Basave, 1982: 105).

La participación es el principio que establece la diferencia fundamental entre la esencia, propia de entes limitados y el ser, característica propia de Dios o del que hace que haya habencia.

Así, con estos principios queda determinada la metafísica de la habencia como una propuesta ontológica de corte latinoamericano que innova en el sentido de la pregunta por el ser y que trasciende el horizonte del ser ubicándolo en la habencia.

\subsection{Ontología simbólica}

Una ontología latinoamericana debe ser significativa, debe tener un sentido práctico sin perder su esencia metafísica; en esta tarea el filósofo mexicano Mauricio Beuchot busca 
acercar la ontología a la antropología por medio de una ontología simbólica fundada en la relacionalidad, esta vez entre la substancia y las relaciones que de este se desprenden y desde la referencia y el sentido. Esta relacionalidad se basa en el complemento ontológico que forman la sustancia, o ente o manifestación física del ente y lo accidental de este. Con la propuesta de la ontología que mira a la antropología

la sustancia se nos vuelve significativa si sabemos conectarla con la relación, esto es, si tratamos de desvelar lo más posible las relaciones en las que, por así decir, la esencia realiza su existencia (o tal vez haya que decir, mejor, en las que la existencia ejerce la esencia que le corresponde (Beuchot, 2012: 167).

Esta propuesta ontológica busca comprender, a partir de fragmentos y la forma de relacionarse, la totalidad del ser, en la que el humano que la interpreta hace parte de tales fragmentos, sus relaciones son las que le dan el sentido por esa carga de emocionalidad y de sentimientos «pues de otra manera viviría él (el hombre/mujer) en el solo espacio del concepto sin el afecto, de la referencia sin el sentido» (Beuchot, 2012: 169).

La ontología simbólica propuesta por Beuchot rescata el existencialismo humano como el que orienta el sentido de la filosofía y de la ontología como tal; soportado en la interpretación misma que se hace de la vida es que se busca hacer una metafísica que diga algo al hombre actual. En este sentido, atendiendo a que «no se da la substancia sin la relación, ni la relación sin la substancia [...] la substancia da la referencia y la relación el sentido» (Beuchot, 2010: 124), es en el hombre, en la persona, donde el sentido adquiere un significado que se aplica a una totalidad entendida como la sociedad.

Desde Beuchot, la ontología simbólica se vincula necesariamente con la filosofía del hombre porque es este quien hace una interpretación de su experiencia más allá de lo puramente referencial o substancial y se dirige a lo relacional que le otorga el sentido propio como hombre/mujer (persona) y en la misma vía a aquello con lo cual se relaciona. Lo anterior parte de la búsqueda de un punto medio entre las filosofías que privilegian 
estrictamente la substancia, entre ellas al hombre como en ente más entre otros entes, y las que destacan con primacía la relación, provocando una disolución de la substancia; de modo que

Hace falta, pues, una filosofía que junte esos fragmentos, que vea en ellos una totalidad; que trate de conjurar substancia y relación, que les asigne un lugar justo y proporcional, de manera que resulte una antropología filosófica que no descuide ni el carácter relacional del hombre ni su estructura substancial (Beuchot, 2010: 125).

La ontología simbólica pasa entonces por una ontología de la persona, donde el énfasis no se hace en el mero hombre como tal, ni en las relaciones como aisladas, sino que orienta su mirada para interpretar una totalidad comprendida entre las relaciones que lo envuelven y que produce, sin perder el sentido de equilibrio entre estos dos complementos.

La aparente oposición entre substancia y relación es superada en la ontología de Beuchot cuando se dirige a la fuente del sentido de las relaciones; el filósofo mexicano plantea una analogía entre esencia y existencia en la que lo substancial solo es referido por medio de la razón, captando así su esencia, en tanto que «en la dimensión de la existencia están, sobre todo, las relaciones que surgen a partir de la substancia, que se mantienen, principalmente, con otras substancias [...] en especial están las relaciones que tiene el hombre con sus semejantes» (Beuchot, 2010: 126) en las cuales la emoción y el sentimiento otorgan el sentido (existencial) simbólico de los elementos inmiscuidos en la relación, «pues de otra manera viviría el [hombre] en el solo espacio de concepto sin el afecto, de la referencia sin el sentido» (Beuchot, 2010: 127).

El símbolo es referido por Beuchot en dos instancias, una aplicada a la ontología de modo que esta adquiera un sentido concreto y la segunda como el elemento de interpretación del que la ontología se ocupe; aquí es el ícono el ser, no expresado como una cosa sino comprendido más allá de su referencia, mirando su sentido como complemento del concepto. El símbolo, en la propuesta ontológica de Beuchot, es el elemento mediador entre 
lo sensible y lo inteligible tal como lo metafórico y lo alegórico revelan aspectos de la realidad que la sola argumentación racional no pueden decir, porque partiendo de lo emocional se sitúan en el sentido; el símbolo provoca el tránsito entre lo sensible y lo inteligible, lo físico a lo metafísico.

Cuando descienden los conceptos ontológicos pasando por los temas antropológicos (vida, muerte, angustia, gozo, etc) se revisten de simbolicidad, adquieren connotación simbólica, se vuelven símbolos ellos mismos, y, entonces sí, el hombre puede captarlo y aplicarlos de una manera más adecuada a su propia existencia (Beuchot, 2010: 131).

Es aquí donde la ontología que se ocupa de la existencia, más allá de la esencia de las cosas y se ocupa de aquellos aspectos a-substanciales que preocupan al hombre, cobra un sentido para la misma existencia; sin dejar de tener como punto de referencia lo abstracto, se conecta con las abstracciones que configuran el universo de emocionalidad y sentimiento para vincularse con lo humano, pero con lo humano envuelto en una red de relaciones generadoras de emociones que no pueden ser definidas, porque no es el interés de la ontología, pero sí comprendidas en el mismo existir; es una ontología que busca el sentido mismo de la existencia.

En la ontología simbólica propuesta por Beuchot la hermenéutica juega un papel esencial como mediadora entre la substancia y el símbolo. A través de la hermenéutica el hombre puede, en la interpretación que se haga del mundo, hallar el sentido del mismo. «La hermenéutica analógica que acompaña y sirve de instrumento a esa ontología analógica (simbólica) debe tratar de concordar y equilibrar, es decir, de proporcionar o dar proporción a las substancia y a la relación» (Beuchot, 2010: 136).

No obstante, tal como se pretende encontrar una ontología que supere la rigidez a la que ha estado sometida, la hermenéutica aquí aplicada no procura establecerse desde la univocidad de modo que restrinja la capacidad polisémica del universo simbólico y de la experiencia humana, sino que esté en capacidad de abrirse a las diferentes formas de existencia y de 
interpretaciones de la misma; por esta razón se requiere de una hermenéutica analógica que interprete el símbolo desde un sinnúmero de significados, sin caer en relativismo y equivocidades.

Tomando en cuenta que el símbolo representa la unidad entre dos aspectos al parecer diferentes, Beuchot se apoya en Gadamer, para quien desde la hermenéutica se puede hacer ontología; aun cuando Gadamer lo plantea desde una ontología del arte; «[para] Gadamer, la obra de arte proporciona una experiencia de unidad, y por eso es símbolo» (Beuchot, 2013. 124) porque une lo universal con lo particular, lo objetivo que da la obra en sí (presencia) y lo subjetivo que es el modo en que es representada para quien la observa (o para quien la elabora).

El filósofo mexicano extiende esta lectura a un amplio campo de las representaciones simbólicas de la existencia humana como el juego y el rito donde la representación se hace simultáneamente con la presencia, «esa simultaneidad es la temporalidad de la obra de arte y del juego y de la fiesta (i.e del símbolo). Es el tiempo del símbolo [...] que une, que conecta pasado y futuro con el presente» (Beuchot, 2013: 126). Del mismo modo el juego y la obra de arte presentan y representan, conjugan en un mismo instante dos fragmentos de la realidad para dar una interpretación de lo verdadero que no puede comprenderse tomando los elementos constitutivos por separado.

Dado lo anterior, la ontología simbólica pretende ser una ontología que va más allá de lo puramente nominal y definitorio del mundo, busca mantener distancia con los preceptos aristotélicos que ven en la substancia únicamente el objeto de ser del ser; mira las afecciones y relaciones de lo substancial para dilatar el espectro de lo ontológico. Por medio de la hermenéutica analógica, encontrar el sentido de existir, no como una substancia esencialista, sino como un sujeto relacional que comprende su existencia en la medida que la emocionalidad le permite entender el nivel simbólico de sus relaciones y la de sus semejantes. El símbolo funge pues como mediador entre el mundo exterior y el mundo creado por el hombre para encontrar el sentido de existir y darle valor al ser. 


\subsection{El ser y la existencia en categorías quechuas}

El filósofo peruano Mario Mejía Huamán, nos presenta en su obra Teqse (2011) una propuesta de pensamiento andino, del cual surgen algunas categorías del idioma runasimi (idioma de los hombres) o quechua con las cuales se fundamente la filosofía peruana, con extensión a Latinoamérica. Tales categorías surgen de la forma como es expresada la representación del mundo que se hace mediante la palabra, esta «significa expresión [...] la palabra es un instrumento de expresión y ella irrenunciablemente es simbólica, es decir, es todas maneras oculta y enmascara la realidad objetiva» (Mejía, 2011: 31); dicho de otro modo, de una cosmovisión única que se dice o se escribe. En este caso la cosmovisión andina permite orientar la reflexión filosófica a partir de categorías propias, entre ellas el ser, el estar y el haber expresados por el vocablo kay.

Entendido que la visión de mundo de los Andes y la europea son diferentes, puesto que

La visión tawantinsuyana fue mítica, mágica religiosa, estética y racional, pero de ninguna manera científica o filosófica. [...] porque para que la visión del mundo haya sido científica era necesario que previamente se considerara al mundo como un objeto independiente [y] tampoco se había dado una ruptura entre la religión y el saber (Mejía, 2011: 43).

Las categorías para el análisis filosófico, aunque se relacionen con las de la filosofía tradicional, buscan ser asumidas de una forma propia, atendiendo a tanto a la universalidad del pensamiento filosófico como a las distinciones entre las formas de concebir el mundo o cosmovisiones; en esta medida, Mejía Huamán procura alinearse con algunas categorías de la Metafísica de Aristóteles, más precisamente el libro quinto, traduciendo su significado y su sentido en lengua runa simi para que, según el autor peruano, «no solamente [se traduzcan] las categorías filosóficas del griego al quechua, sino dejar abierta la posibilidad que algún quechua hablante o quechua-pensante pueda, en algún momento, hacer una reflexión filosófica en quechua» (Mejía, 2011: 201), sin que esto quiera decir que la labor 
de la filosofía andina se convierta en la mera traducción y repetición; se plantea reconocer las bases del pensamiento filosófico y atender a las necesidades propias de la realidad andina (y latinoamericana).

\subsection{1 kay, el ser}

En Teqse se analiza esta cuestión a partir del sentido ontológico del verbo quechua kay el cual «equivale al einai griego, esse latino y al ser castellano» (Mejía, 2011:209), lo cual no deja de presentar algunas confusiones porque tanto en griego como en latín, ser y haber se encuentran definidas bajo el mismo concepto, en tanto que en el castellano no lo es. De esta forma el problema del ser en el sentido quechua no solo se remite al ser de las cosas sino a las cosas que hay necesariamente.

Para el análisis del problema del ser en categorías de pensamiento quechua, es necesario hacer la distinción entre las dos formas en que se presenta el concepto naturaleza, la primera como fisis que remite necesariamente a la naturaleza material, «modo natural de ser, esencia, [...] estatura, porte, aire actitud» (Mejía, 2011: 213), más bien orientado a lo que se puede percibir con los sentidos, dejando de lado la naturaleza espiritual.

La otra forma en la que se presenta el concepto de naturaleza va ligado a la terminología latina que tiene sustento en lo que nace, «proviene del verbo latín nascor, nasceris, nasco sum. Este término a su vez procede del arcaísmo latino gnatus, a, um: nacer y este a su vez del griego gnenea: nacimiento; procedencia, prole, posteridad; lugar de nacimiento» (Mejía, 2011: 213). En este marco la naturaleza también se puede entender en el mundo (concreto y sensible), remitido a lo que tiene vida y se proyecta en el tiempo, lo cual excluiría a lo que hay en el mundo pero que carece de vida como los minerales.

El filósofo peruano prefiere situarse en la primera definición ya que esta abarca la totalidad de las cosas y como totalidad se enmarca en el vocablo quechua pacha, mas, para dar 
fidelidad a que tales cosas en su naturaleza remiten a su esencia «más propio sería usar kay, que significa ser, ser de las cosas, modo natural del ser, esencia» (Mejía, 2011: 215), con lo que queda definido que el ser de las cosas solo está en las cosas que hay en el mundo (pacha) y que tienen los seres en sí mismos en tanto que son. La unidad de ser y haber se expresa en quechua de forma tal que decir que «hay una casa en la plaza» (Mejía, 2011: 217) tiene el mismo sentido de "una casa en la plaza es", «no sería incorrecto afirmar que en el mundo andino que lo que es tiene necesariamente que haber, que el ser es algo (kaqqa kanmi) y que la nada no existe (mana kaqqa manan kanchu)» (Mejía, 2011: 219), esto sería tanto como afirmar que hay cosas que no son o que hay cosas que no son tal; por lo tanto lo que hay tiene su ser en sí mismo.

\subsubsection{Kashay, el existir}

En el análisis de las categorías filosóficas hecho por Mejía Huamán el existir cobra relevancia, tanto como el ser; si bien el ser, Kay, queda definido como lo que hay y el sustento de ello, el existir aparece como la forma activa en la que el ser se manifiesta, «kashay (estar siendo, existiendo, y habiendo) es el gerundio del verbo kay (ser), luego adquiere su forma propias y puede ser conjugado como cualquier verbo» (Mejía, 2011: 229).

Tal conjugación del ser revela la forma de concebir el mundo en el pensamiento andino de forma dinámica, sin que esta característica le reste identidad a lo que es. La prolongación del ser como existir, en su forma runasimi, «expresa el ser dinámico y continuo de una persona; dinámico porque siempre va cambiando, y sigue siendo porque a pesar de estas cambiando sigue siendo el mismo» (Mejía, 2011: 229). No obstante, no se aclara que el existir sea únicamente empleado para la existencia humana o para otro tipo de 'seres'; todas las referencias aportadas en Teqse apuntan a preguntas «¿Qué estas siendo? ¿Dónde estas yendo? ¿Quién estas siendo?» (Mejía, 2011: 229) las cuales solo pueden ser respondidas con un lenguaje expresivo en conceptos, dejando al existir en una dimensión humana. 
Sin embargo, el existir en sí denota una orientación, al parecer, fija; tal dirección supone una ruta o camino que se recorre en la vida, así «cuando se pregunta por la edad: Hayk'aykitan rishankiqa? (tus cuántos están yendo) o Hayk'aykipin kashankiqa? (en tus cuántos está siendo) expresa las mismas situaciones»(Mejía, 2011: 229) donde existir se refiere al ir (por la vida).

Si bien el existir se muestra como una extensión activa del ser como verbo, en quechua se establece la diferencia entre ser y existir, «la categoría de ser se utiliza para aquello que es por naturaleza o es un atributo que se ha alcanzado por el sujeto y se convierte en su naturaleza, dicha cualidad es trascendental al espacio y tiempo» (Mejía, 2011: 229), es decir que el ser es lo que permanece en el cambio, en tanto que el existir hace también referencia a lo que se es en un instante determinado de la vida; en otras palabas al componente dinámico. Empero, este 'devenir' dinámico se aplica tanto a entes finitos como infinitos, haciendo surgir una unidad conceptual entre lo que siempre esta siendo (existir) y lo que se es (ser).

Aunque el existir se refiera a lo humano, el filósofo peruano traza una zanja que lo deferencia del ser existencial occidental: el hombre andino es consciente de vivir en un tiempo/espacio (pacha), pero la muerte no se concibe como un final y dejar de ser, sino como una transformación, «porque desde tiempos inmemoriales, se concibió que la muerte era el cambio de un pacha a otro» (Mejía, 2011: 231), lo cual permite explicar tanto la permanencia del ser como del existir.

\subsection{Ontología animista en el Amazonas}

Este apartado pretende enfocarse en la categoría de la ontología animista desarrollada por Kapfhammer en su artículo para la revista Indiana Número 29 (2012) el cual se explica teniendo en cuenta el principio de relacionalidad como característica principal, donde todos 
los seres (de la selva) están interconectados por una mente o alma común que se manifiesta en la personalidad.

El principio de relacionalidad, como aquí se toma, no se refiere a que estas se presentan en un segundo momento emanadas de los entes, sino que estructuran una totalidad' primera, un principio del que provienen las cosas. La característica principal que interconecta los entes «no es el resultado de una inferencia o 'emanación' a partir de un solo ente, principio o sustancia» (Estermann, 2009: 126) sino que compete a todos los entes relacionados de igual manera dando sustento a una personalidad manifiesta.

De acuerdo a lo propuesto por Kapfhammer, el concepto de personalidad no se remite únicamente a un ámbito antropocéntrico de lo humano; la personalidad es una condición trascendental a los seres de la selva que permite establece una comunicación entre todo lo que allí se encuentra, así «these persons are a "communicative community"1» (Kapfhammer, 2012: 150) en la cual todo está interconectado por su nombre dado.

La ontología animista tiene en cuenta que las relaciones entre las realidades no-humano y las humanas dotan de sentido el mundo de la vida estableciendo una sinergia de bienestar cósmico y humano (Roszak en Kapfhammer, 2012: 147), en el mismo sentido sostiene que estas relaciones tienen un proceso de maduración que se va desarrollando mediante el ciclo de la vida (individual) y adquieren un carácter cultural; de modo que la conciencia de la personalidad relacional pasa por un proceso de aprendizaje únicamente logrado por medio de la experiencia de la vida.

No obstante, dadas las actuales circunstancias del mundo industrializado y de desarrollo económico que pone en riesgo los ecosistemas selváticos, se plantea otro tipo de relaciones entre lo humano y lo no-humano que va en contravía de lo expuesto anteriormente. Estas relaciones se conocen como 'relaciones críticas' porque irrumpen con el equilibrio y el bienestar de los seres de la selva y es manifestada en 'dolores de mundo', como una

\footnotetext{
${ }^{1}$ Traducción personal de la cita: [esa personalidad es una comunidad comunicativa]
} 
sintomatología que busca una 'Gran cambio' orientado a una vida auto-eco-sostenible (Kapfhammer, 2012: 148), a una reestructuración del equilibrio

La posibilidad de un enfoque animista en la ontología, dado en que lo que es, puede entenderse como una 'fuerza espiritual' o ánima, revelada en todo lo existente en el mundo, recobra vigencia en la crisis de la modernidad que ha llevado a mirar otras formas de asumir vías diferentes a las antropocéntricas que «is considered the basic cause of our

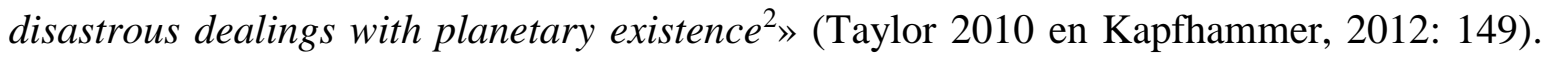
La propuesta de la ontología animista busca tener una visión 'vital' del ser, en la que todo está cargado de vida y atravesado por un ánima (personalidad) que establece relaciones entre las personas (humanas y no humanas) y que permanece en el mundo por medio de la comunicación y la nominación de las cosas.

According to their beliefs, rainforest animals (yaropë) were part of an ancient human population that lost its human shape when the world began. They were humans with animal names [...] They violated the rules of their world - something which is referred to in many myths of the Yanomami -, and thus transformed themselves one after the other, in hunting animals. This is why the Yanomami believe that all animals they chase in the forest are their former human predecessors ${ }^{3} \quad$ (Kapfhammer, 2012: 149).

El ánima, como principio, cuando el mundo inició, hace referencia lo que permanece en las diferentes especias que habitan la selva; a pesar del error cometido por los 'primeros' humanos, mas su esencia queda, siendo en esta sobre la que se sustentan los lazos comunicacionales y relacionales. El ánima se comprende, no como una sustancia, sino como una condición transtemporal porque se presenta antes de la creación del mundo, y

${ }^{2}$ Traducción personal de la cita [es considerada la causa básica de nuestros desastrosos tratos con la existencia planetaria]

${ }^{3}$ Traducción personal de la cita [de acuerdo a sus creencias, los animales de la selva (yaropë) eran parte de una antigua población humana que perdió su forma cuando el mundo comenzó. Eran humanos con nombres animales [...] Ellos violaron las reglas de su mundo -a lo cual se refieren varios mitos yanomami-, y luego fueron transformados ellos mismos, uno después otro, en animales de cacería. Esta es la razón por la cual creen que los animales que persiguen en la selva eran su anteriores ancestros humanos] 
metafísica porque va más alá del mundo experimentable con los sentidos; una condición que da el ser (en el caso del mito) a los animales de caza, a los humanos y a sí misma como personalidad siempre presente; ánima de la que solo los humanos pueden ser conscientes, pues son quienes tienen la facultad de dar los nombres y comunicarlos.

Esta perspectiva ontológica que toma elementos del perspectivismo de Philip Descola y de Viveiros de Castro, caracterizada por la presencia de lo relacional, que además busca mejorar las relaciones entre los humanos entre sí y los seres no humanos dotados de ánima, está soportada a su vez en un suelo ético de reciprocidad y de respeto, en el cual se erigen fundamentos morales sobre la forma en la que 'se debe ser', tanto en humanos como en no humanos.

El enfoque animista de la ontología abarca más allá de lo que se podría llamar los entes existentes del mundo de la selva cuando abarca el ordenamiento de lo-que-es y de la forma en que estos seres han-de-ser, estar y relacionarse:

People belong not only to a human community, but to a community of all nature as well. Existence in this larger society, just as existence in a family and tribal context, places people in an environment in which reciprocal responsibilities and mutual obligations are taken for granted and assumed without question or reflection ${ }^{4}$ (Callicott, 1989: 189-190; cit. in Nelson, 2005; cit en Kapfhammer, 2012: 152).

De acuerdo a Kapfhammer, el animismo contiene algunas características al definirlo como categoría ontológica; se sostiene que «For one, the Amazonian person or "multi-vidual" is always the result of a multitude of external relations and as such subject to diverse

\footnotetext{
${ }^{4}$ Traducción personal de la cita [las personas no pertenecen únicamente a la comunidad humana, pero si a una comunidad de toda la naturaleza como tal. La existencia en esta gran sociedad, como una existencia en contexto tribal y familiar, pone a las personas en un ambiente en el que las responsabilidades recíprocas y las obligaciones mutuas son tomadas para conceder y asumirlas sin ninguna pregunta o reflexión]
} 
historical trajectories» ${ }^{5}$ (Kapfhammer, 2012: 154), en otras palabras la personalidad 'amazónica' (no referida únicamente a la humanidad) no se presenta como un individuo, sino como multividual, hace parte de una compleja red de relaciones que lo ligan a múltiples dimensiones, que superan lo animal, lo humano, lo natural y lo cultural

La ontología animista tiene en cuenta no solo una dimensión del ser, sino que ve al ser, o este es entendido como un conjunto de relaciones que lo forman y que a su vez forman otras posibilidades de ser.

En la cosmovisión de algunos pueblos del Amazonas el sentido del mundo y del ser está dado por una papel de lo sagrado, de tal forma la relacionalidad animista de las personas del Amazonas se presenta arraigada al lugar de origen en tanto que consideran tal lugar de ser, y de existir como un regalo sagrado; así el bosque es vivido y comprendido como un dador de alimentos y de cuidados. El mundo se comprende como una unidad viva, interrelacionada que necesita recibir en la misma medida eso que da, es decir cuidados.

En la ontología animista amazónica, destaca Kapfhammer, todos los seres tienen una 'madre' que ofrece parte de su ser para alimentar y cuidar a las demás personas, esta es contactada ritualmente por medio del anciano sabio o pajé, cuya labor, además de la de guiar el grupo espiritualmente, consiste en hacer efectivas y materiales las relaciones 'metafísicas' entre los seres de la selva, por ejemplo por medio de la provisión de alimentos; de esta manera el pajé -relata Kapfhammer-

He danced with a calabash of guaraná (sap'o) in his hand. He took his rattle and shook it while singing. At that time we strongly believed in him. Because it was the first time that he did this. After he had stopped dancing, he said: 'I'm sure the pack of peccaries will arrive! You can already prepare your weapons in your homes. But you have to take accurate aim, because if you fail, the pigs will only be hurt and will die at

\footnotetext{
5 Traducción personal de la cita. [para algunos, la persona amazónica o "multi-viduo" es siempre el resultado de múltiples relaciones externas y como tal un sujeto de diversas trayectorias históricas]
} 
some other place. That will be no good!' The next day the pack of peccaries arrived at his port. ${ }^{6}$ (Plácido de Olivera en Kapfhammer, 2012: 156).

Aquí se revela el modo que opera una ontología animista, es decir muestra que el ser de las cosas posee y es en sí un alma que se hace efectiva en relación con las de otras personas, pero que se ofrece como un misterio que solo el anciano sabio descubre por medio de rituales a los cuales se llega con el tiempo de la adultez.

La relacionalidad presente en la cosmovisión amazónica sustenta la categoría de ontología animista en la medida que el hombre (en este caso) está sujeto en una intrincada red de relaciones no solo con su especie, sino con el mundo no humano, que se presenta de modo simbólico y que precisa de un pajé que ritualiza tales relaciones y un sentido ontológico de las mismas, dado en la reciprocidad de las relaciones que mantiene una bien-estar de la comunidad y de la misma selva.

\subsection{El sentipensar ontológico, una propuesta sustentada en la afectividad}

El profesor colombiano Juan Cepeda H. ha dedicado gran parte de su obra y de su vida académica a encontrar la respuesta a la pregunta por el ser y a la pregunta pre $\mathrm{lm}$ sentido de ser. Sin embargo, en su calidad de filósofo representante y exponente de la filosofía latinoamericana, ha buscado dar respuesta al interrogante por el ser desde su propio estar, es decir, teniendo en cuenta su configuración cultural y existenciaria.

De este modo, en las apuestas por tratar el problema ontológico desde la perspectiva latinoamericana el profesor Cepeda (2010a) revela que aquél ón griego no hace referencia a

\footnotetext{
${ }^{6}$ Traducción personal de la cita [Él bailó con una jícara de guaraná, (sap’o) en su mano. El tomó su cascabel y lo sacudió mientras cantaba. En ese momento nosotros creímos en él fuertemente. Porque era la primera vez que él lo hacía. Después dejo de balar y dijo: 'estoy seguro que un grupo de pecaríes llegarán! Ustedes preparen sus armas y sus hogares. Pero deben tener puntería y precisión, porque si fallan los cerdos serán heridos y morirán en otro lugar. Eso no será bueno! Al día siguiente un grupo de pecaríes llegó a su puerta]
} 
una cosa, sujeto/objeto, sino a un constante conjugación del ser o un siendo aplicado a loque-es, definido como lo 'siente' o como lo que está siendo. Lo anterior comenzó a revelar la fundamental diferencia «entre ser y ente, es decir entre lo metafísico que abarcan todos los seres, con lo que es (siendo), en concreto, como este o aquel ente» (Cepeda, 2010a: 23).

El autor propone, entonces, ubicarse en un lugar de comprensión diferente al de la tradición filosófica en la que el uso privilegiado de la razón, en detrimento de la esfera sensorial y afectiva, ha elaborado (y creído en) prejuicios que ponen la cuestión ontológica, ya sea como un asunto que no es de incumbencia del pensamiento latinoamericano, o como un cuestión ya resuelta que no es menester volver a mirar.

Con base en estos prejuicios el profesor Cepeda busca, si no desmarcarse de la tradición filosófica, «querer comprender su pensamiento (el de los grupos llamados primitivos) mucho más que querer acomodarlo a los moldes ya elaborados por la filosofía, o mejor, por una determinada filosofía» (Cepeda, 2012: 18), en otras palabras buscar un horizonte más amplio de comprensión del sentido de ser que ofrezca unas categorías diferentes a las 'ratiocéntricas'.

La aplicación de la apertura del horizonte hermenéutico, como método para la investigación metafísica latinoamericana, pretende superar las limitantes del pensamiento 'ratiocéntrico' asociado a individualidades; en este sentido y en el contexto latinoamericano donde de acuerdo a la tradición aborigen lo plural, colectivo y múltiple predomina sobre lo individual, es en los intersticios relacionales que se indaga sobre el ser, no ya como cosas 'ónticas', sino en la amplitud del sentido. La apertura hermenéutica posibilita entender las formas de sentir y de pensamiento desde Latinoamérica.

Con la apertura de horizonte, la propuesta de Cepeda se ubica en la vinculación del sentir y el pensar, el sentipensar ontológico desde el cual no se busca apalabrar al ser no más y reducirlo a meras categorías conceptuales y racionales; es a partir de la emocionalidad, y es 
esta forma de comprender la afectividad [que] seguramente nos obligara a volver hacia atrás unos 24 siglos y sin desentrañar la retórica de Aristóteles, partir precisamente de allí, tras de un original horizonte que permita la interpretación de los afectivo no como simple desvirtuado psicologismo a veces sin razón, superficial y poco efectivo, sino como posibilidad óntico-ontológica propia del ser-del-ser humano (Cepeda, 2007; 15).

Por medio de lo sentido en la experiencia de la vida se permite comprender el ser en una extensión más amplia de lo-que-es, en la que el ser-que-comprende se sitúa en el mismo ser, guardando un estrecho vínculo afectivo en el que la vida, el ser y el estar se funden en un mismo sentido.

La apuesta del ser en el sentipensar es desarrollada por medio de poesías que más que enjuiciar por medio de argumentos racionales lo que es siendo, dotan de sentido existenciario y cultural el ser y el estar.

Sentipensar. Porque no queremos pensar al modo occidental. No.

No queremos pensar categorías abstractas ni conceptos bien fundamentados en teorías racionales e ideales.

Queremos verdadear lo que somos,

lo que estamos siendo,

queremos dejar expuestas las tripas en nuestros textos:

lo que queremos es apalabrar sentimientos y sentimentalidades existenciales que emergen desde lo que son, desde lo que estamos siendo, verdaderamente sentido; es decir: sentido-existencial, visceral, no mero sentido semático, hermenéutico, textual (Cepeda, 2015: 2). 
Así, el sentipensar se funda como la manera latinoamericana en la cual lo-que-es no se ubica únicamente en un plano 'ideal' y abstracto, difícil de asirse en lo concreto; el sentipensar ve el ser en las cosas, sin la reducción óntica, en la verdad de lo que somos y de lo que es. El sentipensar encuentra el ser en el interior mismo, donde emerge para revelarse por medio de los sentidos, las sentimentalidades y el puro sentido de ser.

La propuesta de sentipensar el ser no se puede desligar de los postulados del argentino Kusch porque estos le dotan de una fuerza que invierte el paradigma 'ratiocéntrico', sustentándose en la lógica de la negación, negándola y absorbiéndola por las formas de estar que se encontraban encubiertas en la lógica de la afirmación. "La lógica de la negación/ como sentipensar lo hasta ahora meramente pensado/ para apañar un sentido de vida/ de lo que es/ ha sido el método con que se han avanzado/ estas investigaciones» (Cepeda, 2015: 2). Con este método, la investigación por el ser se extiende tanto como es posible para abarcar en sus diferentes maneras el ser de lo-que-es.

La fuerza es lo primero que aparece revelado al sentir-se el ser o sentir-se en el ser,

Hemos sentido la fuerza que guarda el corazón de la piedra, y la fuerza de la nube gris que trae consigo la tormenta, y la fuerza del viento que nos habla de otras fuerzas, y la fuerza de la pequeña semilla que se abre paso de entre la tierra y va emergiendo en su verdor.

Fuimos fuerza en la gestación, y con fuerza vinimos a este mundo: abrimos los ojos y la boca 


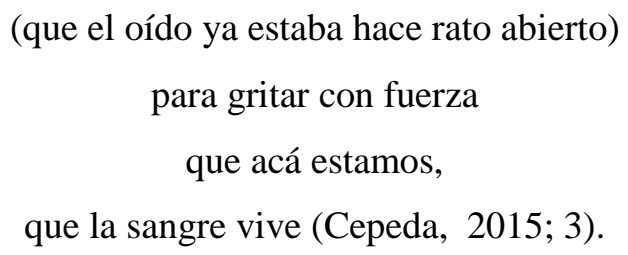

Además del sentipensar, la apertura hermenéutica posibilita hallar el ser más allá de los entes físicos; la fuerza como fundamento del ser aparece como eso que le da el ser a todo lo que ocupa un espacio en el universo; es fuerza aquello que sustenta el paso de potencia en acto, tal como se referencia en la semilla, que por sí sola, se abre paso para adquirir su ser. La vida como tal, como experiencia nuestra del ser, también se manifiesta en la fuerza con que se grita para dar cuenta que existimos y estamos (viviendo).

Empero, la fuerza ontológica no se manifiesta más que con ritmo y así el ser cae en música como esa manifestación de la emocionalidad del ser; «música es el alma de todo ser humano./ Música produce el alma de cada ser humano» (Cepeda, 2015; 4) pero no se limita al ser del humano, pues habita en todo lo demás y para comprenderla no solo «iHay que escuchar!/ ¡Hay que saber escuchar!/ ¡Hay que aprender a escuchar!/ ¡Todo el universo no es/ más que una hermosa partitura viva/ que no deja de ritmar!» (Cepeda, 2105: 4). El ser se sitúa entonces no en la comprensión por raciocinio exclusivo sino que retorna a la sensibilidad de los sentidos y la emocionalidad.

En las aproximaciones a la ontología en perspectiva latinoamericana el profesor Cepeda escudriñó en la música andina el ser, y apoyado en la filosofía de la música de García Bacca (1990), encontró que la música expresa análogamente el ser; las notas y los silencios definen el ser y el no-ser como una armonía de elementos indiscernibles, sin los cuales la melodía (del ser) no puede definirse ni identificarse.

«Tra la la lá. /No somos más que pentagrama/ vitalmente sonorizado/ en las notas de la vida» (Cepeda, 2015; 5), tal como la melodía y la canción se componen de notas, silencios, ritmos y fuerzas, así el ser; un pentagrama vacío, una nota y un silencio sin estar en 
conjugación no hacen nada, no son, y si un pentagrama es solamente leído desde la racionalidad no es más que un código de notas en un orden, mas cuando es oída la música, no importan los elementos, solo el ser de la canción, pasada por la emoción del autor, del intérprete y del escucha son los que hacen notar el sentido del ser, de la melodía, del tono y la fuerza. 


\section{LO ANDINO EN LA FILOSOFÍA ANDINA DE JOSEF ESTERMANN Y SUS FUNDAMENTOS ONTOLÓGICOS}

El hallazgo de los fundamentos ontológicos en la filosofía andina de Josef Estermann, no puede realizarse sin un momento previo, dentro del mismo capítulo, de aplicar una descripción que dé cuenta de lo andino como fenómeno filosófico y reconozca, a su vez, la importancia de Josef Estermann tanto para el desarrollo del pensamiento andino, como para la filosofía latinoamericana.

\subsection{El fenómeno de lo andino}

El presente apartado tiene como propósito abordar la categoría de lo andino que Josef Estermann aborda en su obra Filosofía Andina. Sabiduría indígena para un mundo nuevo, desde una descripción fenomenológica surgida de la lectura de los presupuestos hermenéuticos metodológicos empleados por el filósofo suizo. Además, se tiene como objeto describir el método aplicado por Estermann para establecer la filosofía andina.

Para darle tratamiento fenomenológico se intenta acudir al concepto de fenómeno utilizado por Martin Heidegger en su obra Ser y tiempo (1998), ya que ambos autores, aunque su preocupación objetiva es diferente, recurren a una filosofía de la existencia y de la experiencia vital: Estermann desde una postura intercultural y situada en un topos diferente a Europa y Heidegger desde una actitud centrada en su continente; lo cual es tomado en cuenta como punto de cruce entre los dos filósofos.

Se recurre a Heidegger y la influencia que recibió de su mentor Husserl, de quien adoptó el método fenomenológico y lo llevó a aplicarlo en sus trabajos sobre el desarrollo a la pregunta por el sentido de ser. De este modo, el filósofo alemán hace su aporte al capítulo, 
tanto en el desarrollo de una filosofía que toma como punto de origen al hombre y su modo de estar en el mundo, como en su método fenomenológico de la investigación.

Este apartado se divide en cuatro secciones. La primera pone en contexto a Estermann en el momento de la filosofía que acontecía durante su maduración filosófica, además de reconocer la influencia de algunos autores presentes tanto en sus tesis como en la orientación académica. En la segunda sección se abordan los puntos de partida y llegada, los cuales orientan el problema de lo andino como fenómeno. Seguido, como tercer sección, se desarrolla el contenido de lo andino como fenómeno partiendo de tres aspectos que Estermann revela como reducciones. Uno geográfico, que decanta en lo cultural; otro étnico, relacionado con lo lingüístico; uno histórico, que desemboca en lo político. La cuarta sección describe el método hermenéutico de Estermann, en el que se destaca la autenticidad de sus fuentes y la importancia de la experiencia vital en la construcción de un pensamiento andino y la construcción de categorías filosóficas de las que se desprenderán las ontológicas de que se ocupa la investigación.

\subsubsection{Momento de la filosofía de Estermann}

Josef Estermann es un teólogo y filósofo suizo que nació en 1956 en Surcee (Suiza) y se vio impulsado a estudiar teología 20 años después (1976), en los Países Bajos. Allí enfocó su tesis en el teólogo Juan Bautista Metz, del cual se vio influenciado en el enfoque político de la teología, su postura frente al papel de la religión católica y el curso de la historia acontecido durante y después de la segunda guerra Mundial. Dice Metz al respecto de su teología que

[...] he intentado no hacer teología de espaldas al sufrimiento, visible o hecho invisible a la fuerza, que hay en el mundo... Fue uno de los motivos personales para desarrollar una teología política, del paso de una mística trascendental a una mística política del cristianismo (Ruz, Matías, et al. 2008). 
Por tal razón, Estermann adquiere una mirada hacia un otro que ha estado de espaldas a la historia; sin embargo, hasta este punto el suizo se sitúa en un nivel de acceso a la realidad más profundo y complejo, la teología, en el que adquiere bases metodológicas asentadas en la hermenéutica.

Corría el año 1981 cuando Estermann ingresó a sus estudios filosóficos. La historia de la filosofía atravesaba por un momento en el cual parecía agotarse la modernidad como etapa y se ingresaba, de la mano de Delueze, Derrida, Lyotard entre otros, a lo que se llamaría posmodernidad, como una filosofía que buscaba respuestas al modelo social y económico neoliberal que reconfiguraba el orden social, las nacionalidades, las fronteras y la cultura.

\footnotetext{
Podríamos interpretar el posmodernismo como la superestructura ideológica y axiológica de la corriente neoliberal, o con otras palabras, como reflejo intelectual y filosófico de una mentalidad común en las sociedades de abundancia y consumo [...] el "discurso posmoderno" enfatiza la pluralidad principal de modos de vivir y de explicaciones del mundo, es decir, de "culturas" (Estermann, 2001: 119).
}

Este panorama filosófico acompaña a Estermann en sus estudios de Filosofía en Utrech y Ámsterdam, Países Bajos, de los cuales se titula de licenciatura con base en una disertación sobre Emmanuel Levinas. Este acontecimiento le despertaría un mayor interés por la antropología filosófica y lo adentraría en los ámbitos de la fenomenología y el pensamiento de Levinas, situación que abre el horizonte a la filosofía de la Liberación.

Su doctorado lo hace entre dos universidades; vuelve a Lucerna (Suiza) y luego a Utrecht, en la que, dirigido por el teólogo y filósofo Theo Zweerman, redacta su disertación sobre La individualidad y la contingencia: un estudio de los problemas de la individualidad en Gottfried Wilhelm Leibniz (1990). 
Sus estudios lo encaminaron hacia una perspectiva antropológica-filosófica de cara a la interculturalidad, que a su vez lo preparó para su llegada a Latinoamérica, donde de la mano de misiones pastorales y clases de filosofía, iba conociendo un nuevo contexto para el despliegue de sus tesis. Un entorno con serias dificultades económicas, de exclusión social y de negación de otras culturas y fuentes de pensamiento encontró el suizo en Perú.

Además en este nuevo ambiente, se encontraba con una filosofía situada en un territorio que buscaba su identidad y que para 1990 ya había construido un discurso 'propio' y auténtico de las manos de Dussel y «la filosofía de la liberación que surgió a partir de 1969, [la cual] tiene como trasfondo intelectual tres fuentes importantes: el pensamiento marxista, la teoría económica de la dependencia y la teología de la liberación» (Estermann, 2001: $133)$.

Finalmente, su trabajo con comunidades indígenas y populares del Perú inicialmente y Bolivia después, le abren la posibilidad de exponer una filosofía andina, en un sentido amplio. La filosofía andina que expone y defiende Estermann se basa en un principio de interculturalidad, en la que se supera el determinismo geográfico de los Andes, toma en cuenta el legado histórico de los incas sin ser una filosofía anclada en un tiempo pasado ni ser una propuesta indigenista (cerrada).

Cuando hablamos del mundo andino, necesariamente necesitamos tomar posición frente a lo que suele llamarse indigenismo, (pan-)andinismo, o inclusive pachamamismo, [...] el indigenismo es un movimiento social-político, [...] el 'inkaísmo (...) pretende un regreso a los valores de la sociedad y tecnología del imperio incaico [...] el 'pan-andinismo' refleja un programa político de integrar la región andina como un espacio económico (Estermann, 2009: 66).

La propuesta de Estermann se muestra, pues, como una alternativa filosófica «una cierta manera englobante (un 'paradigma' en el sentido de Khun) de pensar y concebir y concebir el mundo» (Estermann, 2009: 58), sin reducirse a un determinismo étnico, más bien que 
yuxtapone las anteriores condiciones y tiene sus fundamentos en «modelos, ideas y categorías vividos y experimentado por el runa/jaqui ${ }^{7}$ andino, es decir: la experiencia concreta y colectiva del ser humano andino en su universo físico y simbólico» (Estermann, 2009: 74) en otras palabras, en concepciones praxo-lógicas, no necesariamente escritas.

\subsubsection{El origen del problema de la Filosofía Andina de Estermann, hasta dónde puede llegar su propuesta}

El punto de partida de Estermann se ubica en un momento en que la tradición filosófica universal se mantiene cerrada a otras filosofías que prescinden de un sistema escrito y que, por lo tanto, quedan excluidas de la contribución al desenvolvimiento de la tradición filosófica. El teólogo y filósofo suizo se encuentra con que estas modalidades de pensamiento y de conceptualizaciones del mundo (filosofías) reciben un tratamiento de mitos y cosmovisiones, incapaces de construir categorías de pensamiento; así, «en el debate de la 'filosofía incaica' y 'andina' se viene usando, como argumento contundente contra su posible existencia, la referencia al hecho de que la cultura inca (y andina) hubiera sido una cultura ágrafa, y ergo no filosófica» (Estermann, 2009: 76).

Dado lo anterior, Josef Estermann procura argumentar la validez de la existencia de la filosofía andina basado en la problematización y reflexión que del mundo se hace en el contexto andino; parte de la construcción simbólica experimentada en el mundo andino, además de la posibilidad que abre la interculturalidad de manifestar las experiencias vivenciales a través de una variedad de medios y formas como el modo de vivir, la organización social, los ritos, las costumbres, entre otros. Dichas experiencias son

\footnotetext{
${ }^{7}$ Runa/jaqui hace referencia al ser humano en el mundo andino, esta concepción se presenta en tres sentidos: un sentido estricto que hace alusión una raza pura establecida antes de la llegada de los españoles; un sentido amplio en el que significa el hombre andino sin más determinación que la cultural; y un sentido universal en el que representa al ser humano como persona humana. Sin embargo, en su obra prefiere acercarse al sentido amplio cultural. Para el presente artículo se nombrará como sujeto andino ya que se encentra 'sujetado' a una realidad geográfica y cultural del contexto andino.
} 
'concebidas' e interpretadas directamente como fuentes vívidas que permiten captar y apropiarse intelectualmente del mundo.

Así las cosas, Estermann también arranca de la apertura que ofrece la filosofía intercultural, en tanto que permite 'escuchar' la pluralidad de voces y de 'paradigmas' filosóficos que el mundo globalizado muestra; entre esta apertura, las múltiples posibilidades de establecer conceptos, categorías y métodos diferentes de la tradición hegemónica occidental; «una pluralidad radical de paradigmas filosóficos y culturales. Según el "principio de tolerancia", ningún discours (discurso en el sentido de "paradigma") tiene el derecho de concebirse como el "verdadero” y 'más adecuado'» (Estermann, 2001: 120).

Un tercer punto de partida de la propuesta del autor de la Filosofía Andina es el momento en el que se encuentra la filosofía latinoamericana. Aquí la alternativa expuesta por el suizo procura darle una contribución al pensamiento auténtico en dos vías; una intercultural (ya mencionada) y una de la mano de la filosofía de la liberación. En esta última, la motivación, si bien toma en cuenta las condiciones económicas, se orienta al aspecto cultural del cual es preciso encontrar una independencia, en este sentido «rescatar la 'sabiduría popular' del ser humano andino es de por sí un acto de liberación, pero sobre todo un deber y un gesto de reconocimiento de la 'otra' y el 'otro' y su modo distinto de concebir el mundo» (Estermann, 2009: 73), dejando ver de este modo la influencia que ejerció Levinas en las ideas del pensador suizo.

El punto de llegada de la propuesta de Estermann está en la consolidación de su propuesta y en la construcción de categorías propias que no requieran de un parangón con las categorías dominantes y tradicionales sino que emerjan con independencia y se postulen en la misma historia de la filosofía; no tanto como categorías sucedáneas que reemplazan lo existente al nombrarse de forma diferente, sino a manera de aportes y tesis con suficiente grado de autenticidad, pero sin perder validez universal. Al respecto afirma Estermann que: 
Para la tradición occidental dominante, la 'filosofía andina' es algo inédito y externo a la totalidad de la filosofía europea. La 'liberación' consiste en dos momentos: la deconstrucción y desmitificación del 'totalitarismo' filosófico occidental, y la reivindicación de la alteridad filosófica andina (Estermann, 2009: 73).

Se considera así, que el punto de arribo de la propuesta andina se desprende de la filosofía de la liberación, mas dentro del mismo margen busca, más que reconocimiento e identidad, situarse como un saber crítico-científico capaz de adentrarse en los distintos niveles de complejidad y profundidad de la realidad, no solo de 'lo andino' sino universal; pero «el intento de hacer 'sonar' esta voz disonante de la 'filosofía andina', es a la vez un cuestionamiento a la usurpación hegemónica de la razón filosófica por occidente» (Estermann, 2009: 73) que hace ver lejano tal punto de llegada y se constituye, a manera de círculo, en punto de origen y problema.

\subsubsection{Lo andino como fenómeno, un problema para describir}

El abordaje de lo andino se efectúa a partir de lo que Heidegger, en su obra Ser y tiempo, describe como fenómeno. Se pretende aquí describir como fenómeno 'lo andino' en la medida que se presenta a sí mismo como 'algo-que-es' pero no como ente. Se tiene en cuenta que el concepto de fenómeno se define en varios sentidos, pero que guardan relación de uno y otro modo. Así, 'lo andino' se busca describirlo tomando en cuenta uno de los sentidos para no oscurecer ni el concepto de fenómeno, ni el de andino como categoría.

A partir de la definición primera que se hace del fenómeno como «lo que se muestra a sí mismo [y] en lo que algo puede hacerse patente» (Heidegger, 1998: 39), lo andino entra en tales características en tanto se muestra a sí mismo, sin estar reducido únicamente a lo patente ante los ojos, sino que se experimenta sensorialmente usando más que la visión y como un modo de estar en el mundo que dota de sentido el ser. Es fenómeno en la medida 
que sobre la base de 'lo andino' hacen presencia modos de ser y de concebir la realidad, que a su vez se muestran a sí mismos, pero en los que lo andino los hace visibles.

El problema que enfrenta Estermann en sí es lo ‘andino’ como concepto y categoría en la filosofía andina; no obstante, al interior de la Filosofía andina (2009) plantea algunas dificultades internas metodológicas

que tienen que ver con la conceptualización misma de los supuestos contenidos [...] la naturaleza y accesibilidad de las fuentes; el carácter epistemológico de los conocimientos adquiridos; el sujeto del filosofar andino, criterios hermenéuticos en la explicación de la sabiduría implícita; el carácter de la racionalidad que esté inmersa en la metodología a seguir; el problema de la (in)conmensurabilidad de conceptos filosóficos ('equivalentes homeomórficos) (Estermann, 2009: 57).

Lo andino como categoría y problema es tratado en dos aspectos básicos que hacen de este un fenómeno multifacético, «multicultural, multi-étnico y -hasta se podría decirsincrético» (Estermann, 2009: 71) ya que se muestra de distintos modos que requieren de variados significados que no se excluyen sino que se complementan.

\subsubsection{Lo andino como geográfico}

El modo en el que se presenta aquí el problema se refiere un reduccionismo espacial en el cual queda subsumido lo andino a hacer parte de una región natural que comparte los límites con los del imperio inca en su esplendor. Así, lo andino se reduce a la cordillera y el pie de selva oriental.

Este determinismo geográfico se va a mostrar como fundamental en la construcción del pensamiento filosófico andino ya que las condiciones climáticas y topográficas configuran una cosmovisión particular y una racionalidad andina que desenvuelve un modo de 
concebir el mundo. Aunque no se pueden separar la racionalidad del lugar de origen ni de su tiempo, pues el pensamiento es hijo de su tiempo (y de su lugar), esta condición de unidad y relación tampoco puede considerarse como la base para la elaboración de un sistema de pensamiento que se desee imponer como universal.

Empero, en la búsqueda de un fundamento de la filosofía andina solo equiparable con la de otros lugares donde se erigen sistemas filosóficos, dentro de los amplios limites que ofrece la interculturalidad, Estermann se apropia de este problema para justificar que el desarrollo de la filosofía depende de la cultura y esta a su vez del espacio geográfico donde se desenvuelve.

El espacio geográfico y topográfico de los Andes es determinante en parte para la elaboración de un pensamiento filosófico propio tal como lo eran -mutatis mutandisel paisaje costeño en Jonia para la filosofía griega o la región fluvial del Ganges pala la filosofía índica [...] la situación geográfica y topográfica de 'lo andino' es entonces la condición 'material' o le caldo de cultivo imprescindible y a la vez singular para el surgimiento de distintas culturas y un cierto modo de concebir el mundo (Estermann, 2009: 60).

El condicionamiento espacial de lo andino como atributo de la filosofía, si bien se muestra esencial en tanto define la cultura, se supera en la medida que va a estar relacionado con otras significaciones que aparecen sobre esta categoría, lo cual va a permitir ampliar su horizonte de comprensión y complejizarlo para sustentar el desarrollo de una filosofía andina.

\subsubsection{Lo andino como étnico}

Derivado de la condición geográfica y cultural, lo andino se va a presentar dentro de los límites puramente antropológicos como un asunto étnico que, en un primer momento 
parece, circunscribirse en una 'raza pura' precolombina. Esta condición asumida independiente y sin relación con lo demás va a presentar una filosofía de corto alcance que no lograría alcanzar una validez universal, si quiera dentro de un entorno intercultural; bajo este precepto, una filosofía andina se subsumiría a ser un recuento de saberes particulares encargado de enfrentar problemas y preguntas absolutamente locales, con códigos de lenguajes cerrados que impedirían mostrarse frente otras etnias $y$, de referirse exclusivamente a la pureza étnica de los habitantes andinos prehispánicos, no darse la posibilidad de confrontar problemas filosóficos actuales y de lo que se encontraría en el exterior.

Por lo tanto, lo andino como étnico se expone por fuera de tal determinación histórica y abarca «al ser humano que se siente identificado con y arraigado en el ámbito geográfico social y cultural andinos» (Estermann, 2009: 61). En este sentido, lo andino como una categoría étnica se desarrolla en términos de la implementación e interiorización de los idiomas autóctonos para la construcción de una filosofía que asimila problemas filosóficos universales.

Lo anterior permite que el pensamiento andino se despliegue desde su interior a una exterioridad en la cual las categorías de la filosofía tradicional se hacen manejables y comprensibles cuando entran en contacto con las formas culturales propias de los Andes por medio de sus vocablos, aunque se presente el riesgo de la traducción y de la imposición de categorías no existentes endógenamente. «Hasta hay intentos de reivindicar los idiomas runa-simi y aimara (respectivamente en su síntesis "quechumara") para la expresión filosófica como lo demuestran los trabajos de Mario Mejía Huamán» (Estermann, 2009: 78).

\subsubsection{Lo andino como inca}


Un tercer aspecto del problema de lo andino como categoría es la confusión presentada entre el pensamiento inca y el pensamiento andino. Tal situación se exhibe partiendo de las coincidencias geográficas que tienen tanto el imperio inca como la región de los Andes, lo cual ha llevado que se hayan identificado indiferentemente lo uno con lo otro y ubica una situación histórica fuera de contexto temporal; es una derivación del reduccionismo étnico mencionado anteriormente pero con implicaciones en el ámbito filosófico porque conducen a que la filosofía andina se reconozca con un «afán nostálgico de regresar a una época pasada representada en el Tawantinsuyu»(Estermann, 2009: 70).

La categoría de andino es más amplia que lo inca, dado que lo andino supera tanto geográficamente, pues la máxima extensión del imperio inca y que abarcó gran parte de la región duró aproximadamente del año 1438 d.C a 1537 d.C, como históricamente, porque antes de los incas existían otras etnias con su culturas, que por un lado dieron origen al incanato y de otro fueron absorbidas por el imperio; otras se extinguieron o se trasladaron a otras regiones con tal de no pertenecer al incanato; sin embargo estas culturas prehispánicas ya eran andinas.

La falta de un discernimiento entre lo inca y lo andino ha llevado al establecimiento de una corriente filosófica inca a título de andina o inca-andina que, atendiendo a un purismo étnico, reduce la filosofía a un quehacer histórico anclado en el pasado y que se cierra monoculturalmente. $\mathrm{Al}$ respecto Estermann opta por

una concepción no 'purista' de lo 'andino', en contraposición a las pretensiones del 'indigenismo' e 'inkaísmo' militantes. Lo andino es (como también lo incaico históricamente visto) un fenómeno multicultural, multiétnico y sincrético [comprendo lo andino] como un pensamiento vivo y vigente en la actualidad con raíces históricas muy hondas (Estermann, 2009: 72).

La diferencia entre la filosofía inca y la andina radica en los puntos de referencia que toman cada una: la primera se sitúa en la reconstrucción histórica del pensamiento del 
Tawantinsuyu; la segunda procura hacer una filosofía de la experiencia y la vivencia actual de los habitantes andinos y de los que se sienten identificados con la cultura andina. No obstante, estas visiones del pensamiento andino no se oponen ni se anulan, por el contrario se tocan, se complementan y se integran.

Los anteriores aspectos que nutren el problema de lo andino permiten describirlo como un concepto polisémico que se muestra en diferentes facetas, que examinadas y definidas independientemente no pueden dar cuenta de su magnitud y complejidad. Pese a que cada orden de significación parece distante y distinto, mantienen una relación que hace viable contemplar y reducir lo andino a un modo de hacer filosofía desde un determinado contexto mediado por coordenadas espaciales-temporales, pero con pretensiones de validez universal, así «lo ‘andino’ en la expresión 'filosofía andina' se refiere entonces a todos los aspectos geográficos, topográficos, culturales y étnicos anteriormente expuestos» (Estermann, 2009: 68).

\subsubsection{El método para la filosofía andina}

Para el establecimiento de su filosofía andina, Estermann acude al método hermenéutico tal como se constata en el título de su tercer capítulo. Allí el suizo se enfrenta a realizar una interpretación que no parte de textos escritos sino que busca interpretar y comprender una filosofía basada en la mera existencia del hombre y mujer andinos en condiciones de ausencia de escritura.

Tal situación pone a Estermann en la premura de definir sus fuentes y la forma de analizarlas bajo el método hermenéutico, lo cual lo lleva a contemplar un sinnúmero de interpretaciones que, en aras de poner la filosofía andina en un nivel de universalidad, deben ser expuestas bajo criterios de objetividad y de validez. Así, en este apartado se pretende describir su método y la forma de abordarlo, dadas las condiciones de superar una 
exégesis de textos escritos y la dificultad de argumentar la posibilidad de sacar la filosofía del 'logocentrismo'.

El sustento de la filosofía andina es la experiencia vivida a partir de la cual el sujeto andino crea un universo simbólico, conceptualiza y categoriza el mundo; en este sentido «las concepciones 'filosóficas' son 'praxo-lógicas' e implícitas. Secundariamente y en sentido derivado la filosofía andina es la reflexión sistemática y metódica de esta experiencia colectiva» (Estermann, 2009: 74). La necesidad de interpretar este tipo de experiencias, de primera mano, conduce a que la filosofía andina no sea una historia de la filosofía ni una reflexión de segunda mano en la que las interpretaciones conceptuales que se hacen surgen de textos producidos en el pasado; es una «reflexión de segundo orden: la reflexión (interpretación textual) de la reflexión (interpretación conceptual) de la experiencia humana vivida (interpretación vivencial)» (Estermann, 2009: 75).

El hecho de que las fuentes alcanzadas para el desarrollo de la filosofía andina partan de las vivencias y experiencias concretas de la vida del sujeto andino dotan de autenticidad las reflexiones filosóficas, que brotan de un primer orden de interpretación concreta y simbólicamente. Estermann afirma que «la interpretación conceptual de la experiencia vivida tiene como base toda una expertica ágrafa, pero expresada por una serie de formas 'semiológicas' no-lingüísticas y no-escritas» (Estermann, 2009: 75) las cuales se reproducen en una conciencia colectiva.

El método hermenéutico aplicado por Estermann no solo se limita a las experiencias vivenciales ágrafas, también en cuenta toma los aportes que la 'filosofía inca' encuentra para la reconstrucción histórica:

No solamente los khipu (cuerdas de diferentes tamaños con múltiples nudos), sino también los topaku (símbolos e ideogramas simétricamente ordenados) en el ropaje de los nobles y lo qero (vasos de madera o racila decorados con incisiones y 
pinturas) ocultan probablemente una simbología lingüística aun no descodificada (Estermann, 2009: 77).

Las estructuras simbólicas y estéticas son también fuentes que el filósofo suizo reconoce como expresiones de las experiencias vivenciales. Estas no se circunscriben en lo andino exclusivamente sino que dan soporte a cada filosofía auténtica como fuentes prefilosóficas; como lo sucedido con el mythos griego asumido como una 'palabra' metafórica que se aplicaba a una realidad experiencial y sentida, sin la cual el desenvolvimiento de la filosofía no se hubiera presentado. En el mismo sentido, estas fuentes rescatadas por las filosofías inca y andina fungen como metáforas que explican un sentido de las experiencias bajo su propia racionalidad.

El método hermenéutico empleado por Estermann se presenta en cuatro niveles que van desde la experiencia directa con la realidad hasta la reflexión sobre la misma filosofía; de estos niveles toma el segundo y tercero para el desarrollo de su filosofía andina, en tanto se enfoca en la experiencia de estar en el mundo y el modo en que este adquiere sentido. El primer nivel es la realidad cruda, interpretada como una cosa en sí misma a la cual se accede, de primer momento de una forma no-racional teorética sino por medio de una experiencia integral con y en la misma realidad sin distinguirse lo objetivo de lo subjetivo; este nivel «solo juega un papel como presupuesto o ideal heurístico de la misma experiencia integral» (Estermann, 2009: 82), en otras palabras, la realidad cruda se presenta como aquello donde solo es posible la experiencia.

El segundo nivel es la experiencia vivencial que es en sí una interpretación del mundo adecuada al interés de sujeto andino en la que «experimenta su entorno 'real' mediante una codificación cultural que obedece a necesidades físicas y sociales» (Estermann, 2009: 80) que le permite hacer una valoración aun no necesariamente conceptual sino 'cosmovisionaria. 
El tercer nivel se conoce como la interpretación conceptual y sistemática en la cual se conceptualiza lo ya vivido e interpretado, pasando a ser una (re) interpretación de lo ya interpretado. Con todo ello, esta no se reduce a una interpretación de la realidad en sí, sino que se hace sobre la experiencia que se hace en y sobre la realidad.

El cuarto nivel, de interpretación histórica de la misma filosofía busca una reflexión, no ya de la realidad sino de la historia de la misma filosofía. En este nivel, dice Josef Estermann, se corre el peligro de volcarse sobre sí misma y perder contacto con otras historias de otras filosofías.

Teniendo en cuenta la descripción de las formas en que lo andino se presenta como fenómeno es más claro dilucidar el punto desde el cual las categorías de la filosofía andina se han elaborado siguiendo juiciosamente la experiencia del hombre andino y cómo interpreta su existencia en su contexto. De la comprensión de lo andino en referencia al problema del ser es que surgirá la categoría ontológica con sus fundamentos, que le son propios en su forma de vivirlos e interpretarlos, mas no exclusivos dado que realidad relacional, totalidad y sentido de ser ya han sido habladas en otras latitudes; no obstante en el mundo andino se ofrecen auténticamente, arraigadas a lo simbólico y reafirmando su realidad y veracidad.

\subsection{Fundamentos ontológicos}

Una vez descrita la categoría de lo andino en la Filosofía andina de Estermann, se expone un horizonte de comprensión desde el cual se buscan los fundamentos ontológicos, que parten de una experiencia directa con la realidad. Es en el habitar el mundo andino donde surgen las formas de decir lo que es que en este apartado se despliegan de tres formas: la relacionalidad como como el modo de ser, la pacha como la totalidad y la chakana como el símbolo del sentido de ser. 


\subsubsection{La relacionalidad de todo, un modo de ser}

Para comprender la relacionalidad desde la postura de la Filosofía andina como uno de sus fundamentos ontológicos es necesario, primero, tener en cuenta que esta categoría hace parte de un tipo de racionalidad situada en su propia época y cultura, a la cual, en el caso andino, Estermann se refiere como una forma de pensar y representarse (en) el mundo, aunque no siempre implique el uso de la razón y el logos en el sentido estrictamente griego; así, la "'racionalidad' es un cierto 'modo de concebir la realidad', una 'manera característica de interpretar la experiencia vivencial', 'un modo de integral de entender los fenómenos', un 'esquema de pensar', una 'forma de conceptualizar nuestra vivencia', un ‘modelo' (paradeigma) de (re-)presentar el mundo». (Estermann, 2009: 100). Por lo tanto, a partir de una forma particular de comprender lo que aparece en el mundo de la vida y es asumido como realidad y que integra además del 'pensar', las experiencias emocionales, sensitivas y místicas, se define una categoría ontológica con la que se pretende fundamentar ontológicamente la Filosofía andina.

En la racionalidad andina aparece la relacionalidad como un principio fundamental para definir y ubicarse en la realidad, como lo que es (en) el mundo y el estar en él. A lo largo de la obra Filosofía andina (1998 y 2009) este concepto va indicando una dirección ontológica cuando se plantea que sin la relacionalidad el 'sujeto' ${ }^{8}$ ' andino no puede comprender-se en el mundo, pues desde esta lógica andina el principio lógico de todo lo existente no es una substancia que se relaciona con todo lo demás que existe, sino «la relación es -para hablar en forma paradójica - la verdadera 'sustancia' andina» (Esterman, 2009: 108) , ofreciendo un giro lógico a la racionalidad occidental, la cual sostiene que

\footnotetext{
${ }^{8} \mathrm{El}$ sujeto andino no se refiere al sujeto como el humano moderno únicamente sino que su significado se extiende a todo lo existente en la realidad, que desde la racionalidad andina está siempre relacionado con otros sujetos de la realidad. En la racionalidad andina no hay distinción entre sujeto y objeto; para el hombre andino la naturaleza es también sujeto en la medida que ella no es pasiva y está en capacidad de conocer, no solo ser conocida, puesta en conceptos y reducida a objeto.
} 
la relación [...] presupone la 'diástasis' y la dualidad entre por lo menos dos relata que de todas maneras son substancias [...]; en el fondo se remonta a la dualidad entre ‘sujeto' y 'objeto' [...]. El terminus a quo es el 'sujeto' [...] de la relación a entablar, y el terminus ad quem es el objeto [...] de la relación. Pero la relación misma es algo 'accidental', tanto del terminus a quo, como del terminus ad quem. (Estermann, 2009: 108).

La oposición que propone este giro implica que en la filosofía andina no importa la sustancia como primordio, es la relación el primordio entre dos sustancias 'segundas' necesariamente vinculadas en la relación; desde la racionalidad de occidente, la relación es accidente, no esencia, de una sustancia, pero si esta sustancia se relaciona con otra, esta otra no sería segunda sino co-existente; no obstante no podrían existir dos sustancias primeras como sujeto o como objeto. Esta dificultad se ve superada en la filosofía andina al tomar la relacionalidad como principio no sustancial de lo que es y hay en la realidad.

Así, la realidad se ve vinculada a este principio de relacionalidad, comprendida cuando se presenta ante con el hombre/mujer andino, de modo que la realidad se encuentra siendo, no como un ente ab-soluto aislado, sino por los nexos vinculantes que le hacen ser percibida. La realidad está conformada por entes sustanciales que no están aislados o en sí, sino que hacen parte de un entramado de relaciones; «lo que la ontología occidental llama 'ente' ('sustancia' en el sentido aristotélico), para la racionalidad andina es un 'nudo' de relaciones, un punto de transición, una concentración relacional» (Estermann, 2009: 109). Para la Filosofía andina los elementos constitutivos de la realidad no son el fundamento de la misma, sino que están sujetos a la relaciones, que al entrecruzarse revelan un equivalente homeomórfico a la sustancia aristotélica.

Para tener una idea de la relacionalidad es posible dar una mirada al filósofo de Leipzig, Godofredo Leibniz quien en su obra La monadología hace referencia una 'necesaria relación' entre las substancias simples en las que la naturaleza busca mantener una especie de equilibrio, como cuando 
Dios, al comparar dos sustancias simples, [se] hallan en cada una razones que la obligan a acomodarse a la otra $\mathrm{y}$, por consiguiente, lo que para ciertos aspectos es activo, es pasivo bajo otros puntos de vista (...) Ahora bien; este enlace o acomodamiento que tienen entre si todas las cosas creadas, hace que cada sustancia simple tenga aspectos y relaciones que expresan las demás, y que sea por consiguiente un espejo vivo y perpetuo del universo (Leibniz, 1889: 24).

Si bien, Leibniz plantea una relacionalidad entre las sustancias simples para dar cuenta de la realidad, y que esa relación es necesaria, no es principio de la existencia de la realidad, sino que está intrínseca en las cosas; es decir, las cosas y todo ya han sido creados como tal y la forma en que se relacionan es un aspecto de segundo orden. No obstante, el planteamiento del filósofo alemán es útil como guía para comprender la relacionalidad en la constitución de la realidad y lo que es.

En la racionalidad andina el principio de la relacionalidad también se hace patente en la construcción linguiística de los hablantes de las lenguas quechua y aimara. «En los idiomas quechua (runa simi) y aimara (jaqi aru) el punto concentrador de la oración es el verbo» (Estermann, 2009: 109). En estos lenguajes el énfasis de lo hablado no se hace sobre el sujeto y lo sustantivo como en la lengua castellana y otros idiomas europeos; desde esta racionalidad andina el énfasis se hace sobre el verbo el cual funge como relacionador y dota de sentido la oración al estar acompañado siempre de sufijos que denotan una relación reflexiva o recíproca en la que los sujetos no aparecen separados sino vinculados como en una unidad, así, por ejemplo «la oración relacional castellana "él me da a mi” (...) refleja la estructura 'lógica' de la racionalidad occidental de los relata ("él” y "mí") y de la relación ("da"). Sus equivalentes en quechua "qowanmi" y aimara "churituwa" resume toda relacionalidad interpersonal (...) de forma no separada (Estermann, 2009: 110)», demostrando que en la lógica andina la relacionalidad se establece como un principio de unidad expresada por medio del lenguaje. 
No sobra resaltar que el punto de partida de Estermann para referirse a la Filosofía andina, se basa en la coexistencia de múltiples racionalidades, por ende variadas lógicas que se expresan en diferentes estructuras de pensamiento, «por eso podemos hablar de distintas 'racionalidades', es decir: de distintos paradigmas de (re-)presentar la realidad» (Estermann, 2009: 124), los cuales dependen de la 'culturalidad' y «aunque la lógica siempre ha sido la piedra angular para la validez 'universal' del pensamiento occidental, no se puede inferir a priori que sus principios lógicos sean de valor supra-cultural o supercultural» (Estermann, 2009: 124). Del mismo modo sucede con los postulados de la Filosofía andina, los postulados, conceptos y fundamentos aquí encontrados alimentan, como lo es la relacionalidad, no se pueden suponer como absolutos desconociendo la interculturalidad.

El sentido ontológico que aquí adquiere la relacionalidad se sustenta en que para la racionalidad andina no existe un ente absoluto o totalmente autárquico y carente de relaciones, «ningún ente existe en y por sí mismo [...] el ser más bien es el 'ser relacionado'» (Estermann, 2009: 128). Con la relacionalidad en clave andina se entiende la realidad de forma holística, como una totalidad, en la que el ser que se revela allí es ubicado dentro de la realidad, porque esta es construida por las relaciones.

Empero tal relacionalidad no se supone como emanada de una sola sustancia, del mismo modo el 'todo' relacionado no se basa en una totalidad analítica sino concreta y real, de hecho «la primordialidad de la estructura relacional no se entiende en sentido metafísico, ni cronológico, sino axiológico y vivencial» (Estermann, 2009: 126) o sea que este principio se encuadra en la misma experiencia vivencial y cotidiana, es una «relacionalidad sui generis que implica una gran variedad de forma no-lógicas: reciprocidad, complementariedad y correspondencia en los aspectos afectivos, éticos, estéticos y productivos» (Estermann, 2009: 127). El mundo concreto, donde se manifiesta la realidad del ser, se presenta de forma holística y demuestra que lo que se define solo tiene su existencia en la medida que son interrelacionados; luego, lo que estuviera aislado sería, 
pues, un no-ente, una situación que implicaría una alto grado de abstracción y se alejaría de lo concreto y 'real'.

Teniendo en cuenta lo anterior, la relacionalidad como fundamento ontológico de la Filosofía andina dista de una idea del ser como una substancia o una condición absoluta, autosuficiente e inmanente. Para hacerlo patente en términos de la lógica occidental, la propuesta de la relacionalidad como categoría ontología afirma que «el 'ser' es más bien el 'ser relacionado; la 'ontología andina' siempre es una inter-ontología» (Estermann, 2009: 128) porque el concepto 'ontología' tiene su origen en lo ente, como substancia autárquica que existe en sí y por sí misma.

Entonces, al partir de la realidad en la que están involucrados tanto los entes como los acontecimientos, estados de la conciencia, las posibilidades y lo sentimientos, esta solo es posible en tanto 'pertenece' a algo. La realidad que es no subsiste como una condición ontológica como tal, es decir que la realidad simplemente es; esta se comprende como parte de algo. Si se toma la realidad como el ser, este no es ser no más sino que es ser de algo, es una posesión o cualidad de un objeto, siendo entonces lo que fija el entramado mismo de lo que es y hay: «la 'realidad' (como un 'todo' holístico) recién 'es' (existe) como un conjunto de 'seres' y acontecimientos interrelacionados» (Estermann, 2009: 128).

Al hacer tomar en cuenta la lengua quechua es posible percatarse que para referirse a lo que es en la realidad se hace uso de la palabra kay, que bien se emplea inicialmente como verbo que indica el ser y el existir, pero tal vocablo no solo se refiere al verbo que implica que algo hace parte de la realidad siendo, también se refiere a la posesión o pertenencia de algo, de modo que kay al expresarse como ser o existir inmediatamente hace referencia a que eso existente mantiene una relación de corresponsabilidad o que 'le pertenece' a alguien o algo.

En el mismo sentido «el mismo vocablo kay se usa como adjetivo y pronombre demostrativo con el significado de 'este', 'esta' o 'esto' (kay qhari: 'este varón'; iman 
kay?: ‘qué es esto?’) (Estermann, 2009: 128). En otras palabras el uso del vocablo kay se orienta a demostrar que lo que es la realidad y lo que en ella hay existe, no de forma separada, sino como relacionada con algo más y que eso mismo a lo que se refiera está en un 'aquí y ahora' pues se puede demostrar como un 'esto' concreto.

No obstante, desde la filosofía occidental se ha procurado reducir la relacionalidad a un mero relativismo, lo cual, como ha quedado expuesto anteriormente, ubica al ente como principio ontológico y el vínculo relacional como accidente (secundario). Lo mencionado tiene sus bases en lo que se ha dado en llamar como principio de plenitud manifestado expresado en dos planos; En el metafísico se afirma que

El universo está lleno, es decir: que no hay un vacío entre los entes, [que] todo está conectado en continuidad ontológica y contigüidad óntica. [...] En el plano lógico, el 'principio de plenitud' dice que ‘todas las posibilidades serán realizadas de una vez' es decir, $[\ldots]$ no queda ningún campo óntico desocupado (como posibilidad enteramente potencial).» (Estermann, 2009: 129);

es decir que todo está determinado por una posibilidad única referida a una unidad absoluta en el fondo, en la cual finalmente todo está sujeto a un principio 'ontológico' que ocupa todos los espacios reduciendo la posibilidad a una única que se desenvuelve como si fuera premeditada.

Desde la filosofía andina, empero, no es determinante así una unidad ontológica que recaiga en un monismo, pues en esta filosofía la relacionalidad crea en sus vínculos diversas posibilidades que no siempre son de contigüidad directa o causal, «la mayoría de los tipos relacionales son no-causales (correspondencia, reciprocidad, polaridad, proporcionalidad)» (Estermann, 2009; 130); tampoco buscan completar una unidad, sino por el contrario se multiplican las posibilidades casi que infinitamente, «podemos compararlo con el juego de ajedrez [en el cual] las múltiples relaciones entre tablero y piezas son esencialmente normadas (como estructuras posibles) [pero] las relaciones 
concretas (movidas ejecutadas) de ninguna manera obedecen a una necesidad» (Estermann, 2009: 130). En pocas palabras, las relaciones presentadas son esenciales pero no son necesarias como se presentan.

No obstante, aun cuando la relacionalidad adquiere ese carácter esencial, dista de lo que desde la postura occidental se conoce como relativismo, en la que se «refleja el 'principio de connaturalidad' que expresa un paralelismo lógico-metafísico entre el orden ontológico y gnoseológico: 'ser' y 'conocer'» (Estermann, 2009: 131); vínculo aparentemente necesario que pretende determinar lo relacional en la medida que antepone el logos a la realidad haciendo imprescindible el primero para el acceso a la segunda y reduciendo la esencia de la relacionalidad al mero conocimiento inteligible de 'lo que es'.

Por el lado de la racionalidad andina, «la misma 'realidad' puede ser en parte 'opaca' (inaccesible) al logos, y la parte 'transparente' (aletos) puede revelarse a la capacidad 'lógica' del ser humano gradualmente y de forma deficiente» (Estermann, 2009: 131), por lo tanto la realidad no requiere ser representada en conceptos lógicos, por ello no requiere de ser nombrada para 'ser' sino que simplemente está ahí para ser vivida y celebrada.

La forma de ser que tiene la realidad, desde la perspectiva andina de la relacionalidad se presenta liberada de una serie de situaciones que pretenden encasillar a la realidad desde el modo lógico occidental, que encuentra lugares opuestos como lo trascendente y lo inmanente. El ser fundamentado en la relacionalidad no es trascendente y ulterior a lo que es en la realidad, es decir, que la relacionalidad que permite que lo que es sea no existe en una especie de afuera de la realidad, porque «nada ni nadie es 'totalmente trascendente' en el sentido de una 'separación ontológica'» (Estermann, 2009: 133) como la idea de Dios que crea el universo pero está más allá de la realidad. Empero, tampoco la relacionalidad tiene la inmanencia como única forma para ser cual si esta contuviera todo, incluso a sí misma. 
La relacionalidad como fundamento va más allá de estas separaciones y las relaciona en un mismo modo de ser relacional que permite el flujo entre lo trascendente y lo inmanente, donde la realidad (que es) supera tales categorías. El modo en que se define así la realidad desde el hombre andino surge en la medida que este la va conociendo a través de su experiencia de vivirla en la que no la trasciende para conocerla como un objeto sino que se siente integrado en ella; vincula los extremos occidentales de sujeto objeto un una especie de inter-conocimiento, tal cual si la realidad conoce al hombre andino en simultánea al conocimiento que este hace de la realidad sobre sí mismo.

Para el runa/jaqi, la 'realidad' no-humana no es un dato bruto, un simple noumenon regulativo, sino tiene carácter sapiencial [...] la 'realidad' nos conoce en ella y nosotros conocemos la 'realidad' en nosotros; [...] es subjetivo-objetiva, cognoscente y conocida (Estermann, 2009: 135).

El despliegue de la lógica de la relacionalidad andina en el mundo (pacha) cuenta con cuatro principios que la definen como una forma de ser propia de la racionalidad andina. En primer lugar se encuentra la relacionalidad, ya definida como la permanente relación holística en sí del mundo. En segundo lugar la correspondencia, que afirma que todo lo que forma la realidad se corresponde de forma armónica, afectiva y simbólica más allá de la relación causa-efecto; desde la lógica andina este principio derivado de la relacionalidad se presenta de manera simbólica y celebrativa presentando la realidad desde diversas dimensiones que no necesariamente son causales

Aunque este principio es derivado de la relacionalidad como un modo de esta, no debe confundirse como equivalencia o mediación que se sucede entre dos 'sustancias primeras', no debe pensarse como «la relacionalidad occidental trata de concebir la relacionalidad de la 'realidad' (como rasgo secundario con respecto a la 'sustancialidad)» (Estermann, 2009: 136), sino como un modo de ser relacional que permite comprenderlo como fundamento, como tal presente en todos los niveles de la filosofía andina: 
En primer lugar, describe el tipo de relaciones que existe entre macro- y micro-cosmos [...] la 'realidad' cósmica de las esferas celestiales (hana/alax pacha) corresponde a la realidad terrenal $[. .$.$] también hay correspondencia entre lo cósmico y lo humano, lo$ humano y lo no humano, lo orgánico y lo inorgánico, [...] el principio de correspondencia es de validez universal (Estermann, 2009: 138).

Lo anterior expone que este principio de correspondencia, se hace presente en todo lo que existe y se configura como un atributo de ser, en el que se hace patente una relación fundamentada en este principio; así todo lo que es se corresponde a sí mismo y con otros modos de ser, los cuales a su vez le corresponden y son correspondidos en diversas dimensiones (biológicas, espirituales, epistémicas, humanas, entre otras).

El tercer principio, de complementariedad, explica que «ningún ente y ninguna acción existe monádicamente, sino siempre en co-existencia con su complemento específico. Este complemento es el elemento que recién hace pleno o completo al elemento correspondiente» (Estermann, 2009: 139), en otras palabras, la totalidad del ser se conforma de 'entes incompletos' que en la relación de correspondencia se complementan integralmente; bajo la perspectiva andina estos no se excluyen sino que tienen la posibilidad de coexistencia como afirmación de una entidad total.

Tal como se ha referido previamente que ninguna sustancia es en sí y por sí misma, aquí la complementariedad funge de modo que, como vínculo relacional, liga aspectos que por sí solos no pueden tener existencia en el plano de lo real tal como la forma y la materia en el planteamiento aristotélico, al respecto se afirma que «el ‘ente completo' (la deutere ousia o 'sustancia individual') es la coexistencia concreta particular de estos dos principios complementarios» (Estermann, 2009: 139). Y aun cuando materia y forma se complementan para ser un ente particular, este mismo es parte complementaria de otro ser particular, siendo ambos parte y ser. 
Sin embargo al mirar desde el punto de vista de la filosofía tradicional 'occidental', la lógica que ella trae, pasa por alto la complementariedad al entender como opuestas las dos posiciones que en una relaciona de tal índole se anularían, todo ello soportado en el principio de no contradicción occidental, que por un lado decanta en un principio de identidad que afirma la exclusividad y total diferencia de ser de un ente; por otro lado el principio de tercer excluido refuerza la supremacía de un modo de ser sobre el otro excluyéndolo, tal cual sucede con la sujeción de lo existente a ser falso o verdadero y que deja afuera de la lógica tanto a uno de los dos como a una tercera opción, «estos tres principios son la base de la racionalidad de exclusión de occidente, o la racionalidad bivalorada [que admite] (solo dos valores lógicos)» (Estermann, 2009: 141).

Situados en la racionalidad andina, «el principio de complementariedad enfatiza la inclusión de los 'opuestos' complementarios en un 'ente' completo e integral» (Estermann, 2009: 141) que sería una tercera posibilidad que supera la bivaloración occidental. En este sentido se comprende que todo cuanto hay en la realidad tiene su ser en la relacionalidad, sustentada en la complentariedad, no como una entidad particular, suma de dos situaciones previas, sino como una 'tercera' posibilidad única pero no independiente, que a la vez es complemento de otra tercera posibilidad, «'ente', acontecimiento, sentimiento o pensamiento [...] como síntesis de algo (posición) y su 'opuesto' (contra-posición)» (Estermann, 2009: 141).

Al superarse la lógica de la exclusión en la lógica andina, se supera conjuntamente la negación del ser (o el no-ser), puesto que la coexistencia de lo que aparecía como opuesto amplía el espectro del ser mediante la relacionalidad. Lo que la perspectiva lógica de occidente entiende como esa 'contradicción' que lleva a la anulación del ser de una (o de las dos) partes implicadas; la racionalidad andina lo comprende como 'contrariedad' que acepta el ser y respeta la distinción entre las partes. De la forma que se relacionen entre ellas, surge pues ese tercer elemento que junto con los anteriores también es. Todo ello sin dejar abierta la posibilidad de 'no-ser' ni como realidad concreta ni como posibilidad. 
La racionalidad, apoyada en el principio de complementariedad, como fundamento ontológico sin embargo mantiene estrechas similitudes con la dialéctica occidental en la medida que no asume la «'contradicción' como la paralización de todo proceso transformador [...] sino como 'dinamización de la realidad'» (Estermann, 2009: 144); es decir que lo que sería la síntesis hegeliana se equipararía al tercer elemento, a diferencia que como 'síntesis andina' convive con tanto con la 'tesis' y la 'antítesis', las cuales no son abstracciones racionales sino experiencias concretas de la realidad.

Si bien la dialéctica occidental sirve como referente para explicar la forma en que opera este principio de la racionalidad andina, la segunda toma distancia de la primera además de lo mencionado, en que el ser de la realidad no va orientado por una idea de progreso (de la humanidad), o sea que no es una lucha de antagónicos que en su dinámica 'perfeccionan' el mundo, sino que en el encuentro entre contrarios distintos surgen múltiples posibilidades sin una dirección previa, proyectada por la humanidad en busca de una mejor realidad, lo que sucede escapa a la voluntad del runaljaqui andino. Es de aclarar que «la filosofía andina no comparte ni la progresividad, ni la unidireccionalidad de la historia y del proceso cósmico» (Estermann, 2009: 145).

Dicho principio de complementariedad lo demuestra también Miranda Luizaga (1996) en su filosofía andina como una relación de alteridad vinculado a «otro complementario dentro de mi $[\ldots]$, en la pareja $[\ldots]$, en la familia [...], con la naturaleza [...], dentro de la misma sociedad $[\ldots .$.$] y entre sociedades regionales, nacionales e inter-continentales diferentes»$ (cfr. Miranda, 1996: 55-62) en las cuales se busca comprender una forma de 'nosotros' (juwasa) en la que se des-individualiza el ego y se acepta una asimilación de lo otro (como complemento).

Para concluir con los principios de la relacionalidad se explicará la reciprocidad como cuarto principio dentro de la racionalidad andina. Este principio se revela simultáneamente con el de correspondencia en un nivel que trasciende las relaciones entre los runa/jaqui andinos, «no solo rige las interrelaciones humanas (entre personas o grupos), sino en cada 
tipo de interacción, sea intrahumana, entre ser humano y naturaleza, o sea entre ser humano y lo divino» (Estermann, 2009: 144). Es un principio que rige un orden universal 'cósmico' porque ordena la realidad, no a disposición de lo que desea el hombre andino, sino que este también pertenece a este orden y cumple su deber de corresponderse recíprocamente con lo demás que se relacione.

La reciprocidad se define como un condicionamiento mutuo referido a las acciones ejecutadas por cada elemento de la naturaleza a otro; en las cuales, dependiendo del esfuerzo aplicado, se recibe una acción con el mismo esfuerzo para equilibrar la relación.

La forma en que se desenvuelve este principio opera en la justicia de las acciones que implican relaciones siempre buscando mantener estable el cosmos (pacha), de modo que las relaciones 'primeras' corresponden a reacciones de relaciones previas y de forma no lineal porque desde la racionalidad andina «cada unidireccionalidad accional y relacional trastorna este orden [cósmico] y lo desequilibra, [...] la causalidad como relación unidireccional tiene que ser entendida como un momento de la relacionalidad superior que tiene carácter recíproco» (Estermann, 2009: 147).

Este principio no requiere de una igualdad entre los elementos implicados, sino que por medio de sus relaciones se complementen de forma 'circular', de modo que «una relación (unilateral) en la que solo una parte da o solo es activa, y la otra únicamente recibe o es pasiva, para el runa/jaqui no es imaginable ni posible» (Estermann, 2009: 147) porque supondría una constante desequilibrio que terminaría por anular el ser, así que o bien se espera que la 'justicia cósmica' restablezca el orden o que tal acción sea el restablecimiento de una acción previa.

Como fundamento ontológico, la relacionalidad no comprende estos principios aislados, sino que estos a su vez se vinculan estrechamente para operar conjuntamente y dotar de ser y sentido a todo lo presente en la realidad, aun la realidad misma. 


\subsubsection{Pacha, la totalidad relacional}

Estermann acude a la expresión pacha para definirla como el cosmos mismo, en tanto que en ella existe el tiempo, el espacio y la materia; así, pacha tiene su ser, y todo lo que en pacha está siendo lo hace en relación con ella misma y con lo demás que está allí. Sin embargo, este término andino no puede ser traducible en las categorías lógica occidentales ratiocéntricas como un solo concepto equiparable a Tierra o mundo, dado que para Estermann, la homeomórfosis ${ }^{9}$ de conceptos y categorías entre culturas tiene que ver más con la función que realiza la expresión que con el concepto como tal, lo cual la torna en una expresión polisémica cuyo significado puede variar según el contexto y la situación.

Pacha es un vocablo tan rico en significados en la estructura lógica andina que suele ser usado no solo el sustantivo que hace referencia 'la Tierra' y el mundo como tal, sino que se emplea como adjetivo, adverbio y sufijo; cada uno con una denotación particular pero no separada de las otras. Luego, «como adjetivo, pacha significa 'bajo', 'de poca altura', pero también 'interior'» (Estermann, 2009: 156); lo cual hace referencia a un condición espacial y de dimensión que implica un mirar bajo, ya sea hacia el suelo o hacia sí mismo. «Como adverbio su significado es 'debajo' (como el sub latino en substancia), 'al instante' 'de inmediato', pero también 'mismo'» (Estermann, 2009: 156) lo que evidencia una unión entre la dimensión espacial y temporal que en el fondo sugiere la proximidad y el presente, como un 'aquí y ahora' de la realidad.

En la filosofía andina, se analiza la expresión pacha a partir de su configuración 'logica': pacha se interpreta como la relación entre dos vocablos, cada uno con su propio sentido, que vinculados entregan su definición; pacha se compone «(síntesis) del sufijo verbal -pa, con el significado de 'nuevo', 'nuevamente', 'otra vez', 'más', y del sufijo nominalizador

\footnotetext{
${ }^{9}$ Para aclarar, Estermann afirma que "la 'homeomorfia' (de homeion: 'similar' y morphé: 'forma') es una tercera forma de 'equivalencia', más allá de la univocidad y equivocidad. No se trata de un equivalente conceptual en una cultura distinta, ni una oposición equívoca, sino de un equivalente funcional" (Estermann, 2009: 92)
} 
diminutivo - cha, que denota la pequeñez de algo, pero también afecto o despecho hacia el objeto o persona indicados» (Estermann, 2009: 165). De esta forma, su significado podría estar dado como un afecto que se tiene una y otra vez como siempre nuevo (al lugar/tiempo que es y donde se desenvuelve la posibilidad de ser).

Como vocablo aimara, pacha se refiere a totalidad o completo, ya sea al dirigirse a una pluralidad de elementos y la relación entre estos elementos o a la completud de uno solo, «por ejemplo urpachaw irnaqui: 'ha trabajado todo el día [o...] jupapachaluri, lo que significa 'él o ella mismo lo ha hecho; taq pacha: 'absolutamente todo'» (Estermann, 2009: 156); de este modo, pacha puede significar algo análogo a ser, en la medida que implica una totalidad en varios sentidos.

La expresión pacha no solo se utiliza para presentar el mundo concreto; el universo de las posibilidades y la incertidumbre también está cubierto bajo este vocablo rico en acepciones; «como sufijo verbal -pacha- marca una acción dudosa o el proceso de la acción incierta. Este sufijo inferencial puede manifestarse para un tiempo futuro y el pasado testimonial, y se lo traduce 'posiblemente', 'quizá', 'tal vez'» (Estermann, 2009: 157). Desde este punto de vista, que pacha involucre lo que no es patente pero sí como una posibilidad de ser, amplia el horizonte del ser sacándolo de lo estrictamente material y físico, al sacarlo de la dimensión espacio temporal y llevarlo al de las posibilidades.

En el pensamiento andino, ya sea quechua-hablante o aimara-hablante, el término pacha como sustantivo es referido al mundo, ya sea como planeta o como tierra. Sin embargo, este significado se amplía hacia lo que se puede entender como el espacio de la vida donde todo 'es'. Si bien «existe otra palabra quechua para "universo" o "mundo": teqsimuyu, que significa literalmente 'fundamento (teqsi) redondo (тиуи) [,] se refiere al universo físico de los cuerpos celestes» (Estermann, 2009: 157), es decir lo que se entiende como 'espacio exterior, no obstante para referirse al planeta donde se desenvuelve la vida utiliza kay pacha como 'este mundo' o teqsimuyu pacha, indicando que además de ser un cuerpo celeste, este tiene 'todo' y es donde hay vida, «cuando se trata de la 'tierra' como base de la 
vida, se usa en ambos idiomas la expresión pachamama (madre tierra) o simplemente pacha» (Estermann, 2009: 157). Así que la importancia de pacha no es solo el planeta como tal, sino su función vital, en la cual todo tiene su ser, y desde la cual se permite acceder al ser de todo cuanto hay en ella, tenga vida o carezca de ella.

Dado lo anterior se puede afirmar que pacha es un vocablo polisémico suyos significados atraviesan el pensamiento andino, en el cual «pacha significa el universo ordenado en categorías espacio-temporales', pero no simplemente como algo físico o astronómico» (Estermann, 2009: 157) sino que supera, relacionando, las distinciones entre lo material y lo inmaterial, entre lo concreto y lo posible. Para el hombre andino el 'mundo' se presenta en tres modalidades diferentes que se pueden entender como estratos: Hanan/Alax pacha, Kay/Aka pacha y Uku/Manqha pacha; los cuales no están aislados unos de otros, sino que comprenden la totalidad, donde se manifiestan los tiempos y las dimensiones del ser.

De esta manera cumple una función relacional en sí misma en la que las dimensiones de la vida y las categorías del ser se manifiestan unidas. Pacha como fundamento ontológico en la filosofía andina se desenvuelve como la relacionalidad patente, efectiva y posible: «tiempo, espacio, orden y estratificación son elementos imprescindibles en la relacionalidad del todo» (Estermann, 2009: 158) lo que dota de significado de relacionalidad ordenada a pacha como fundamento ontológico.

\subsubsection{La chakana, realización fáctica de la relacionalidad}

Con base en el altar de Coricancha, dibujado en 1613 por Juan de Santa Cruz Pachacuti Yamqui Salcamaygua en el que expresa la su visión del universo ${ }^{10}$ donde se representa el cosmos o pacha, como una casa que contiene todo lo que vive, se realiza una lectura sobre

\footnotetext{
${ }^{10}$ La obra original se encuentra en la biblioteca nacional de Madrid, en el libro Relación de Antigüedades desde Reyno del Piru, este ha tenido ocho ediciones en las quqe se ha intentado interpretar el Altar de Corichancha con numerosas traducciones. Para efectos de la Filosofía Andina de Estermann, se toma la reproducción original y su transcripción que se anexan en la página 322 (2009).
} 
el concepto de pacha como fundamento ontológico en el que todo está y «fuera de la casa (Universo/ pacha), no hay nada; y dentro de ella, todo está relacionado a través de los ejes arriba/abajo y derecha/izquierda» (Estermann, 2009: 162) por medio de un lugar de intersección conocido como chakana en el que las modalidades de relacionalidad mencionadas más arriba encuentran su punto de cruce, esencialmente la correspondencia y la complementariedad. Cada elemento fundante de sentido de ser en pacha cobra su sentido mismo en relación con lo demás por medio de una chakana, el punto donde la relacionalidad cobra sentido y transita lo complementario y lo correspondiente del universo pacha; es un puente que conecta.

El vocablo (compuesto) quechua chakana viene del verbo chakay que significa 'cruzar', 'trancarla puetra o entrada', más el sufijo obligativo - na que le convierte, añadido a un radical verbal, en sustantivo. Chakana entonces es el 'cruce', la 'transición' entre dos puntos, el 'puente' como nexo entre dos regiones. Chaka (en quechua) tambien significa 'pierna' o 'muslo' (en aimara es chara); el 'puente' descansa sobre dos 'piernas' (pilares). Chaka en aimara es el 'puente' (Estermann, 2009: 170 nota 32).

La chakana representa el fundamento sobre el cual se sostiene todo cuanto está en relacionado en pacha, más allá de cruce o puente entre dos puntos, es la misma acción de atravesar el puente uniendo lo que se encuentra a cada lado y en el mismo sentido es lo que sostiene al puente, se podría decir que es la razón de ser del cruce. Así el puente, la acción y la base que lo sostiene definen el carácter vinculante de la chakana que se trasciende su reducción a sustantivo y a verbo, a su vez permite que el sentido de ser pueda ser encontrado en la existencia que se genera en su esencia misma de puente.

Retornando el Altar de Coricancha, aquí es el punto de partida donde se toman los elementos que permiten definir el nexo tan estrecho entre chakana y pacha en el que todo lo que es y hay cobra sentido de ser. En el centro del altar (que representa el cosmos) figura una chakana general (En palabras del Yamqui) «de cuatro estrellas en forma de una 
cruz que se dirige a lo cuatro puntos cardinales (cuatro esquinas de la casa)» (Estermann, 20009; 162) dividiendo y conectando las cuatro zonas del universo-casa (pacha).

De lo anterior resultan dos ejes fundamentales sobre los cuales transita lo correspondiente (arriba/abajo) y lo complementario (derecha/izquierda). «En el eje vertical [...] vemos por encima de la "chakana en general" con la "Madre coca" un espacio en forma de óvalo [que] está totalmente vacío, [con] la siguiente inscripción reveladora :"wiraqocha Pachayachachiq - 'Dios hacedor del Universo"”’(Estermann, 2009: 163) junto con elementos como los astros (sol, luna estrellas) y fuerzas meteorológicas como la lluvia y los rayos, las nubes y el arcoíris; de lo cual se comprende que en la parte superior del puente de cruce central tiene lugar lo que está arriba (hanan/alax) y que de algún modo es grande y hasta superior, así como lo sagrado, ordenando en esta región de la casa lo macro; pero de ningún modo es «el 'más-allá' (trascendente) en sentido metafísico o escatológico» (Estermann, 2009: 173). Por tal razón es de resaltar que aún la misma existencia del Dios hacedor del universo se ubica dentro de pacha como parte integral de la realidad, pues aparece dentro de los límites, donde todo es.

En la parte inmediatamente inferior (kay/aka) de la chakana general, es presentada la pareja humana, junto con los animales y las plantas; la palabra quechua kay, hace referencia al aquí y el ahora, «kay/aka pacha no coinciden exactamente con lo que se suele llamar "tierra"; es más bien la calidad espacio temporal directa y concreta» (Estermann, 2009: 173) y da a entender que esta es la región donde todo está sucediendo y que enlaza lo ulterior de la casa con lo más inferior, además de su connotación espacial y temporal; es una referencia al presente como intersección entre el tiempo que pasó y el que está por venir, del mismo modo la zona de transición entre lo macro y lo micro, es «el 'espacio de la vida', en oposición a uray ukhu/manqha pacha ('región de abajo o de adentro') como 'lugar' de los muertos» (Estermann, 2009: 173).

En el extremo inferior (uary/manqha) del eje de correspondencia se sitúan los cimientos de la casa compartiendo espacio con las plantas y el suelo, lugar donde se encuentra la semilla 
y lo que va ser; al mismo tiempo es a donde ser retorna materialmente después de haber cumplido la existencia en la tierra. Allí está el mundo de lo pequeño, pero no por ello lo inferior en cualidad ontológica ya que todo hace parte de la misma red de relaciones.

La forma en que se corresponden estas 'regiones' de pacha implican que todo cunato sucede en cualquier punto del eje se manifiesta en los demás, tal como los fenómenos astronómicos (macro) inciden directamente en los tiempo de cosecha y cultivvo (micro) a través de lo que se encuentra en el espacio medio como los animales y las personas (andinas); estos se afectan por esta relación al depender existenciariamente de las plantas y de determinadas condiciones meteorológicas. Empero, lo que sucede en la región media (kay) también afecta directamente la existencia de los habiente en la parte más inferior, repercutiendo en la parte más superior.

Por su lado el eje de complementariedad ubica en las regiones denotadas por la correspondencia, la relacionalidad entre lo femenino y lo masculino sobre lo cual se funda esta categoría relacional. Como la pareja central del altar se encuentra mirándonos, se ha de entender que o que aparece al lado del varón (lado izquierdo de la imagen original) son los elementos masculinos y lo que aparece en el costado de la mujer (lado derecho de la imagen original) corresponderá a los elementos femeninos de la 'casa-universo-realidad'.

En la parte superior 'masculina' aparecen los fenómenos astronómicos como el sol, lo diurno y lo claro, las pléyades y la estrella de la mañana (que se relaciona con el planeta Venus); en la misma región superior, pero más abajo se presentan los fenómenos meteorológicos como el rayo y el arcoíris. Ya en la región media en el mismo sector masculino aparece el mundo como tal, y un río. Bajo estos íconos figuran un conjunto de ojos que en la mitología inca hacen referencia a las paqarinas o lugar de nacer o de 'amanecer', como el origen de todo cuanto hay (Cfr. Estermann, 2009: 167 nota 26).

El complemento femenino sin el cual es imposible la vida y la existencia trae los siguientes elementos, ordenados también de forma descendente, es decir de lo macro a lo micro. En el 
plano astronómico esta la luna, por consiguiente la noche y a su vez lo oscuro, junto a ella la estrella de la tarde, que anuncia la llegada del ocaso. La región de los asuntos meteorológicos tiene a la nube, la lluvia y el frio.

Junto a la pareja, en la región media al lado femenino están los animales representados en el puma, que «junto con el cóndor y la alpaca ocupan un lugar predilecto en la ‘cosmovisión' y simbología andinas» (Estermann, 2009: 168). Allí está el mundo acuático y el agua conservada, a diferencia del agua corriente del rio (masculino). Finalmente en la región inferior está el árbol como presentación del reino vegetal y también con una connotación simbólica como árbol genealógico. (Cfr. Estermann, 2009: 168).

Este componente de complementariedad es fundamental en la relacionalidad de la chakana porque ofrece el sentido de totalidad de lo que hay en pacha; según esto tanto lo femenino como lo masculino están presentes en el cosmos, como lo diurno y lo nocturno, la vida y la muerte «son realidades complementarias y no opuestas o antagónicas. Donde hay 'muerte' (el fin de algo viejo), ahí mismo hay 'nacimiento' (el inicio de algo nuevo); esta experiencia se refleja en la concepción andina del tiempo que es circular o cíclica» (Estermann, 2009: 175). En otras palabras, la totalidad de la realidad que se manifiesta en pacha y todo lo allí habiente (material y no material), no puede ser sin la coexistencia de elementos 'opuestos'; de este modo la muerte no implica el fin de la existencia o la anulación del ser, sino que es asumida desde la Filosofía Andina como una condición necesaria para que 'todo' siga teniendo su ser, es una parte fundamental sin la cual la realidad no puede manifestarse de forma existenciaria y vital para el runa/jaqi andino.

La chakana hace presencia en las diferentes modalidades en que se desenvuelve la filosofía andina, por este motivo no pueden pasarse por alto las numerosas veces que es mencionada en la obra de Estermann sin comprender el sentido que adquiere en cada modalidad. Así, se definirá el sentido de la chakana filosófica y la chakana celebrativa. 


\subsubsection{La relacionalidad entre el hombre/mujer andino y su acceso al mundo, la chakana filosófica para conocer el ser en su totalidad}

Para la filosofía andina (en especial la pachasofía), «el 'puente' (chakana) tiene, en cierto sentido, 'prioridad ontológica' con respecto a los extremos conectados o relacionados (relata relationem suppontum $^{11}$ ); la relación tiene, para hablar en lengua occidental, dignidad ontológica, respectivamente ontomórfica» (Estermann, 2009: 181). Este punto de entrecruce de complementos y correspondencia, nombrado como pacha o casa es el fundamento del ser, donde se presentan las relaciones, constituido a su vez de la relacionalidad, «tal vez sea oportuno traducir el vocablo pacha por la característica fundamental de la racionalidad andina: 'relacionalidad'. Tiempo espacio, orden y estratificación son elementos imprescindibles para la relacionalidad del todo [...] podemos traducir pacha como 'cosmos interrelacionado'» (Estermann, 2009: 158).

Al tener en cuenta el esquema del altar de Coricancha, sustento empleado por Estermann para el desarrollo de su Filosofía Andina, las chakanas conectan los espacios del mundo de arriba (hanan/alax pacha) con los inferiores (kay/aka y uku urin/manqha pacha) totalizando lo macro y lo micro, simultáneamente enlazan entre lo femenino y lo masculino, lo claro y lo oscuro haciendo comprensible el sentido de ser o estar en el mundo y del mundo mismo como posibilidad ser.

Para Estermann la forma celebrativa y simbólica que tiene el hombre/mujer andino en su racionalidad provoca un análisis de este 'puente' sustentado, además de dibujo del Yamqui,, en los ritos de despacho que se hacen en el mundo andino, pues «a través del despacho o waxt'a, el universo como pacha está simbólicamente presente ${ }^{12}$; no se trata de una 'representación' conceptual o icónica de pacha, sino de una 'presentación' celebrativa»

\footnotetext{
${ }^{11}$ En la Filosofía andina de Estermann, este aclara que desde el punto de vista de la filosofía occidental el orden se invierte en un relatio relata supponti, en el que la relación es una accidentalidad del ser y no puede ser un ente. (Estermann, 2009: 181 cita 42)

${ }^{12}$ En una celebración de despacho hace presencia elementos de los reinos de la naturaleza: animales como las vicuñas, vegetales como la coca y minerales como el incienso (Cfr, Estermann, 2009: 179 cita 40)
} 
(Estermann, 2009: 177) en la cual el elemento central son tanto las 'personas' andinas como la coca; por medio de la coca el runa/jaqui comprende el ser del mundo. Por ejemplo, este elemento siguiere la correspondencia al provenir de la selva, un lugar de ‘abajo' (uray pacha) para cumplir una función de conectar el runa/jaqi con el espacio de 'arriba' (hanan/alax pacha) donde viven tanto los apus/achachilas o espíritus de las montañas y los antepasados.

En los rituales de despacho en que se presenta el mundo, las hojas de coca simbolizan las 'tres pachas' y al simbolizarlas dan a conocer esa realidad.

La coca es un 'puente' ritual-celebrativo, y por tanto un importante canal de conocimiento. [...] 'Conocer algo' significa sobre todo 'realizarlo celebrativa y simbólicamente' [...] y a través del ritual se 'presenta' el conocimiento que no es un 'depósito' de la persona, sino una relación intrínseca del plan cósmico (Estermann, 2009: 183).

De modo que la chakana, además de ser el mundo en la realidad, es la forma de acceso al conocimiento del mismo, pero no na forma en la que hay un 'sujeto' que conoce un 'objeto' de forma unidireccional, sino una forma práctica en la que el todo (en) el mundo es sujeto de conocimiento por medio de la experiencia ritual que es la mima experiencia vital.

\subsubsection{Ckakana celebrativa, la ubicación del hombre/mujer andino}

Si bien el mundo en la realidad ya hace presencia antes de la existencia del hombre/mujer andino, es por medio de este último que el mundo adquiere sentido de ser dada la participación celebrativa y simbólica que le permite comprender la revelación de la realidad; «el runa/jaqi es una chakana importantísima, un puente cósmico imprescindible, aunque de ninguna manera el único ni el primero [...] no 'recrea' el cosmos en una forma conceptual» (Estermann, 2009: 214) sino que participa de él de forma concreta. 
Su participación que implica el 'conocer' el sentido del 'cosmos' pacha lo lleva al mantenimiento del orden en que se presenta. A diferencia de la apropiación del mundo que sugiere el pensamiento occidental, la racionalidad andina pone al hombre/mujer andinos en una especie de centro del cosmos, ocupa una zona donde convergen tanto lo complementario como lo correspondiente para que todo ello sea continuo, aquí «el ser humano es ante todo 'guardián' (arariwa) y 'conservador de kay/aka pacha, y no dueño o 'productor'» (Estermann, 2009: 215).

Su ubicación como chakana central dentro de la cosmovisión andina le responsabiliza del cuidado no solo de lo que está a su alcance de la mano sino de los fenómenos mayores como los meteorológicos. El trabajo del runa/jaqi se orienta a generar una relación de diálogo, recíproca con la pachamama, de la cual recibe alimentos y cuidados y a su vez le responde con oraciones y rituales.

Como cuidador del orden las relaciones cósmicas la persona, para la Filosofía Andina de Estermann, se reconoce como un fragmento no separado de la totalidad de pacha en el que «se 'concentra' (synballein) en forma muy densa e intensiva el 'misterio de la vida' y del orden universal (pacha)» (Estermann, 2009: 216).

El lugar del runa/jaqi es el de puente entre los fenómeno meteorológicos del mundo de arriba y el mundo de abajo donde se siembra y con la agricultura busca preservar un orden que prolongue la existencia tanto suya como de lo demás que está a su cuidado. En el mismo sentido como parte de la pareja, en el nexo entre lo femenino y masculino se prolonga la vida y «establece lazos entre generaciones y contribuye a la conservación de la vida» (Estermann, 2009: 217), celebrando y ritualizando el mundo como forma de conocerlo.

Vinculando todo lo anterior del capítulo el fundamento ontológico de la Filosofía Andina de Estermann es la relacionalidad y las formas diferentes en que se manifiesta o es 
mencionada; así la relacionalidad es fundamento de ser de todo cuanto hay en el mundo desplegándose en la relación, la correspondencia, la complentariedad y la reciprocidad.

Los principios en los que se despliega la relacionalidad se hacen concretos y patentes en pacha, donde el tiempo y el espacio se funden en un mismo plano en que las relaciones sobran sentido, el cosmos ordenado y el universo mismo construido no en sí mismo sino relacional.

Finalmente la forma de comprensión de la relacionalidad es simbólica, aquí la chakana cumple la función de presentar fácticamente la relacionalidad, manifestándose como la forma en la que el runa/jaqi (se) comprende (en) el mundo, lo celebra y lo conoce. 


\section{CONCLUSIONES}

La investigación sobre los fundamentos ontológicos en la Filosofía Andina de Josef Estermann pretende ofrecer una mirada en suelo propio sobre la ontología; con ello ampliar el espectro filosófico de la metafísica en Latinoamérica a través de la búsqueda del ser, su sentido y su principio entre las líneas que el autor de la Filosofía Andina ha dedicado al pensamiento Quechua y Aimara.

A lo largo del texto en mención Estermann dedicó extensas páginas al análisis comparativo entre distintas disciplinas de la filosofía de corte tradicional y la cosmovisión andina; de allí se desprendieron categorías como pachasofía, dedicada al saber del cosmos; runa/jaquisofía, respondiendo a la pregunta por el hombre; la ruwana/luraña-sofía, como propuesta para la ética y la apu/tata-sofía, como categoría teológica. Todo lo anterior propuesto en clave intercultural para rescatar y validar saberes tradicionales y populares de los Andes, poniéndolos en un diálogo par con la tradición filosófica occidental caracterizado por la autodeterminación cultural sin caer en purismos culturales.

Teniendo en cuenta las categorías anteriores se hizo preciso indagar por otra disciplina filosófica que no aparecía referenciada en la obra, de este modo se buscó responder qué se dice del ser en la filosofía andina. La respuesta se encontraba velada entre las líneas de Estermann, razón por la cual tuvo que hacerse un rastreo hermenéutico que tuviera como punto de referencia a Aristóteles y Heidegger para visibilizar en la tradición los hallazgos. Sin embargo, como es un trabajo que enriquecerá la filosofía latinoamericana tal rastreo se ha hecho tras vestigios de autores del continente como Kusch, Basave, Beuchot, entre otros que han ofrecido miradas auténticas sobre la pregunta por el ser y los diferentes sentidos del mismo.

En un primer momento se evidencia que con el pensamiento escolástico europeo aparece en el continente la pregunta por el ser, sin embargo esta pregunta aun carecía de identidad 
latinoamericana como tal hasta bien entrada la modernidad. Fue con el siglo XX y la mirada hacia el interior la que revela la necesidad de tener una metafísica latinoamericana, situada en la realidad concreta y a partir de allí construir el discurso ontológico.

En Kusch encontramos entonces una propuesta ontológica del estar, apoyada en el pensamiento popular e indígena que recobra la dualidad de Viracocha, presente en el pensamiento indígena andino, y marca la existencia del hombre americano. Tal dualidad no ofrece la estabilidad que expresa el ser de la ontología de corte tradicional, pues el hombre se mueve entre los polos opuestos de la dualidad y le hacen caer en cuenta que en el mundo se está no más, como una forma de arrojo asumida con pasividad.

La propuesta metafísica surgida desde Marquínez es más enfática en la realidad que en el ser mismo; esta se sitúa en esa realidad concreta latinoamericana, para que una nueva ontología se abra paso lejos de idealizaciones y no se quede estática contemplando el ser sino definiendo la realidad para cambiar tal modo de ser en Latinoamérica, víctima de las circunstancias históricas.

Por su lado, Basave propone la Habencia como un principio ontológico previo y ulterior al ser, el cual queda 'reducido' a ser interpretado en el parámetro de lo que hay y tiene en cuenta la existencia antes que la esencia.

En la misma dirección de ontologías existencialistas la ontología simbólica tiene un fuerte componente hermenéutico en tanto requiere de la comprensión del ser asumido como una totalidad de la que se es partícipe. Pero no se llega a él sino por el sentido de ser que se adquiere en la relación con los demás 'fragmentos' del ser. En esta propuesta el papel del símbolo es entendido como el mediador entre las cosas en sí y el concepto que de ellas se hace, el cual no puede haber en ausencia de un sentido. De hecho el símbolo aparece como el elemento que da sentido al existir. 
La mirada 'quechua' ofrecida en la ontología del Kay se apoya en la polivalencia que tiene ese vocablo en la cosmovisión andina, poniendo su énfasis en lo natural, visto no como un objeto inanimado, sino como un sujeto esencial; entonces lo que es o lo que tiene ser se considera como lo que tiene esencia, entendida como el modo natural de ser y que hace parte del mundo material, de las cosas sensibles. En este ámbito ontológico el existir no tiene que ver con la manifestación de la esencia, sino que se asume como una extensión de la esencia, como la participación del ser en el tiempo en la cual se va dinamizando y se capta en precisos momentos del tiempo.

Al interior de la selva la ontología animista del Amazonas tiene en cuenta la relacionalidad y la totalidad. El ser se asume como un gran espíritu cuyo 'cuerpo' se compone de una red de relaciones que trascienden todos los ámbitos de la vida. Esta ontología comparte elementos con la ontología simbólica como la existencia de elementos rituales que dotan de sentido la comprensión de una totalidad de la cual se es un fragmento y pone de manifiesto que el ser depende de mantener un equilibrio recíproco y sagrado en las relacionas que conforman a ese espíritu totalizador.

El aporte del sentipensar ontológico, de influencia 'kuscheana', busca el ser en la misma experiencia de la vida donde se revela la fuerza, como el principio que fundamenta el ser y el sentido del mismo y el ritmo con el cual la fuerza hace su aparición en la naturaleza, alcanzando finalmente una comprensión co-razonada desde la que Juan Cepeda H. propone los términos de fuerza rítmica autopoiética.

Es imperante resaltar los elementos comunes a cada propuesta de la ontología en América Latina; de este modo encontramos que antes que desmarcarse de la tradición ontológica occidental han enriquecido tanto las definiciones sobre el ser como las formas y el sentido de ser.

Ya al situarnos en el problema de los fundamentos ontológicos de la Filosofía Andina de Estermann fue necesario describir lo andino como un fenómeno que supera algunas 
reducciones: lo geográfico de los Andes, cuando toma elementos propios otros paisajes como lo selvático; lo temporal reducido a la cultura Inca, en tanto que toma tanto elementos de imperio de hace casi 600 años como aspectos contemporáneos; finalmente lo étnico, en medida que no solo abarca a los indígenas y campesinos de Bolivia y Perú, sino que se extiende a lo largo de América Latina.

Este fenómeno requirió de una lectura hermenéutica tanto de los textos escritos como de una interpretación y comprensión de las experiencias de vida de los habitantes andinos lo que permitió que se reconocieran fuentes ágrafas en la construcción de la filosofía andina, sin que ello la excluyera de la filosofía universal; por el contrario, se buscó ampliar el radio de acción de este saber involucrando 'fillosofías locales' en claves de validez universal bajo la argumentación lógica, la conceptualización y la reflexión.

Es de importancia la contribución que hace el filósofo suizo a la filosofía latinoamericana al intentar darle un giro para que esta, sin perder su identidad y su carácter político-histórico, se pueda ocupar de algo diferente a la historia de la filosofía e interpretaciones de segundo orden y se arroje a construir categorías que no compitan con las de la tradición universal.

En el trabajo de investigación se pudo evidenciar que el soporte ontológico de la filosofía andina de Estermann no estaba presente explícitamente en su obra. Para revelarlo fue necesario remitirse a la misma lógica 'racional' andina sin la cual sería imposible comprender la forma en la que se presenta la respuesta a la pregunta por el ser.

Así, el componente ontológico está sustentado en un estrecho vínculo entre ser y realidad. Es en la realidad concreta donde tiene manifestación el ser, es más la realidad misma es lo que es. A partir de allí se reconoce que todo lo que es y está en la realidad se encuentra siempre bajo un tejido de relaciones. Luego, el primer fundamento ontológico que va a manifestarse es la relacionalidad. 
Este fundamento es reconocido como lo que dota de ser a la realidad, por ende al ser. Esta mirada relacional del ser, a diferencia de la mirada canónica y tradicional de la filosofía, no se fija en lo óntico sustancial sino que se apoya en las relaciones que dan el ser a todo lo que hay en la realidad (y la realidad misma).

La relacionalidad, desde la racionalidad andina, no es un accidente o atributo secundario de una sustancia sino que es la condición necesaria de ser, tanto porque todo cuanto tiene ser no está aislado de la realidad ni lo que le rodea, como porque en la relacionalidad es que se hace comprensible el ser y obtiene sentido.

La categoría de relacionalidad como fundamento ontológico se apoya en cuatro principios, el de relación holística de toda la realidad: el de correspondencia, que atiende a las relacionalidad entre lo pequeño y lo grande; la complementariedad que afirma que nada existe si no con algún ente opuesto y a su vez los entes son producto de la relación entre opuestos, como lo femenino y lo masculino para generar vida; finalmente la reciprocidad como esa condición necesaria para el soporte de la existencia en la medida que establece un equilibrio entre los nodos de la relacionalidad y que se manifiestan en una especie de circularidad.

El segundo fundamento ontológico es la Pacha, en la cual cabe todo cuanto hay. La relacionalidad es la que define todo lo que es, y es Pacha la totalidad del ser; comprenderla como fundamento ontológico debe superar las categorías raciocéntricas occidentales que la reducen a representación conceptual de mundo y planeta Tierra puesto que en la racionalidad andina pacha es un vocablo compuesto de dos palabras relacionadas, que adquiere diferentes significados relacionados entre sí que amplían su espectro de definición; de este modo pacha comprende categorías espaciales; temporales, y de acción.

Pacha bien puede referirse al 'universo' en la medida que nada escapa al cosmos y todo en él, sin embargo esta categoría ontológica andina incluye también las posibilidades no efectuadas, no solo el mundo presente sino el pasado y el que ha de venir. 
Lo anterior surge de las divisiones del orden del mundo en mundo de arriba (hanan/alax pacha) donde está el pasado y a su vez es el 'lugar/tiempo' a donde irán los espíritus de las personas; del mundo de aquí (kay/aka pacha), donde se manifiesta la realidad fáctica presente y el mundo de abajo/el interior (uku/manqha pacha), donde 'habita' lo que va a ser, las posibilidades y donde se sembró la semilla. Pacha aparece entonces como ese ‘todo' donde la relacionalidad cobra sentido y el espacio, el tiempo y el orden 'natural'.

El último fundamento se comprende como como la realización fáctica de la relacionalidad y como el símbolo de la misma. Tal como el vocablo pacha, chakana está compuesto de dos palabras quechua/aimaras que en su relación ofrecen el significado de puente de cruce que conecta dos lugares diferentes, lejanos y opuestos. No obstante este vocablo no se reduce estrictamente a un sustantivo, sino que es simultáneamente la acción de atravesar y conectar los principios de la relacionalidad.

En la chakana se realizan los cruces de lo macro y atmosférico, con, lo micro y subterráneo, paralelamente se encuentra tanto lo masculino como lo femenino dando lugar al ser, a lo que hay y lo que está; es decir que todos los entes de pacha son chakanas en las que los principios de la relacionalidad convergen, y tal como pacha está dividida en cuatro partes, atravesadas por dos ejes, todo lo habiente en pacha contiene las mismas divisiones y los mismos ejes.

La chakana se presenta en dos modalidades: una como la forma de acceso a la relacionalidad y la realidad en la medida que la experiencia vital del 'sujeto' andino le hace comprensible la relación que mantienen en, con pacha y con lo demás; la chakana es la conciencia del estar en el mundo. Así mismo el hombre/mujer andino es chakana celebrativa, es decir son la chakana que es consciente de sí misma y que asume su lugar en el mundo (pacha) como el encargado de mantener el equilibrio del mismo por medio del trabajo. 
Al dar una mirada general sobre los elementos encontrados se hace evidente que no se puede dejar de lado la influencia de Heidegger en la medida que la respuesta por el ser y su sentido se buscan en la existencia misma del hombre; aun cuando en la experiencia animista no se menciona al alemán, sí tiene suficiente peso la experiencia de la vida y el modo en que se le encuentra sentido a ese ser (o estar) allí en el mundo. Empero, el que se tenga esa influencia, cada propuesta ha mantenido su autenticidad en la forma de definir los elementos comunes, desvelados en la ontología latinoamericana.

De esta manera el ser obedece a una idea de equilibrio sin el cual la vida ni el mundo pueden sustentarse, es claro que donde más se hace énfasis en este aspecto es en las ontologías de corte andino e indígena. Así mismo el ser deja de asumirse como una idea abstracta, provocando que sus vestigios sean buscados en el mundo concreto y real; aquí la realidad protagoniza la ontología por sus características situadas en este continente y porque es tanto inmanente como trascendente a la experiencia del mundo.

El recorrido por la ontología en Latinoamérica muestra que la experiencia de la existencia de la vida es común a todas las propuestas y la adquisición de sentido es lograda por medio de la relacionalidad entre lo simbólico, lo ritual y lo sagrado; lo relacional como 'categoría' estuvo estrechamente vinculado tanto a la forma en que el ser se revela como al sentido de ser, estar o existir que tiene el hombre latinoamericano. En particular, sobre los fundamentos ontológicos de la Filosofía Andina se puede afirmar que estos se plantean en tres dimensiones: primero la relacionalidad como fundamento del ser, segundo Pacha como la totalidad del ser y en tercer lugar la chakana como forma de experimentar en la existencia el ser y el sentido que este tiene (comprensión del ser).

Al hacer una proyección sobre el alcance de estos fundamentos ontológicos surge una pregunta sobre cuál sería el fundamento de la relacionalidad, pues, como quedó expuesto a lo largo de la investigación, esta no puede ser una sustancia monádica ni un accidente de la sustancia. 
Para ofrecer una mirada más profunda sobre este asunto Estermann, en su apartado de la ruwana/lurañasofía o ética andina, aporta algunos elementos sobre el trabajo, el deber y el ser, en los cuales el trabajo o ruwana es la base sobre la que se debe mantener el equilibrio de pacha; por tal razón el trabajo es el deber ser de todo lo que existe, tanto como fuerza productiva como sinónimo de actividad que relaciona las partes entre ellas y con el todo. Esta ética del trabajo supera lo humano y se extiende a todo lo demás como elementos que (se) configuran (en) el cosmos; a la vez es regido por los principios de la relacionalidad que fundamentan el ser. Es decir que todo en el cosmos que entra en relación se sustenta en el trabajo, como una ética 'natural' que mantiene lo que es.

Teniendo en cuenta lo anterior esta investigación sobre los fundamentos ontológicos de la filosofía andina deja abierta la posibilidad que sea ampliada sobre las bases de la ética andina y el papel del trabajo o la acción como la fuerza que hace posible que se mantenga la totalidad de pacha como una constante interconexión de redes de relación. 


\section{Referencias Bibliográficas}

Aristóteles. (2012). [Trad. Valentín García Yebra] Metafísica. Gredos. Madrid.

Basave, A. (1957). Filosofía del hombre: fundamentos de antroposofía metafísica. México D.F/ Buenos Aires. Fondo de Cultura Económica.

Basave, A. (1982). Tratado de metafisica; teoría de la “Habencia”. México.

Beuchot, M. (2003). Hermenéutica analógica. Aplicaciones en América Latina. Editorial el Búho. Bogotá.

Beuchot, M. (2010). Hermenéutica analógica, símbolo y ontología. Universidad Autónoma del Estado de México. México D.F.

Beuchot, M. (2012). Ontología simbólica y Antropología Filosófica: Hacia una Antropología Significativa para el Ser Humano. En J. Cepeda, \& M. Beuchot (Ed.), Aproximaciones ontológicas a lo latinoamericano (págs. 165 - 180). Ross. Rosario.

Beuchot, M. (2013). Hermenéutica analógica y ontología. Centro de investigaciones y Docencia en Humanidades del Estado de Morelos. Cuernavaca.

Cárdenas, et al. (2013). A lo Profundo de Kusch. Tras una ontología latinoamericana. SEmillero MEtafísica y Ontología SEMEyON. Nueva América. Bogotá.

Cepeda, J. (2007) «Bevrijding». Del beso de una caricia. Withy. Bogotá. 
Cepeda, J. (2009, ene-jun). Problemas de Metafísica y Ontología en América Latina. En Hallazgos. Revista de Investigación. Año 6 (No 11) pp.51-72. Universidad Santo Tomás. Bogotá.

Cepeda, J. (2010a). Tras la comprensión del problema de ser. Grupo de Investigacion Tlamatinime. Universidad Santo Tomás. Bogotá.

Cepeda, J. (2010, jul-dic.b). Ontología del estar: aproximación a la obra de Rodolfo Kusch. En Análisis. Revista Colombiana de Humanidades (No 77) pp. 163-177. Universidad Santo Tomas. Bogotá.

Cepeda, J. (2012). Ontología Indígena. En J. Cepeda, \& M. Beuchot (Ed.), Aproximaiones Ontológicas a lo Lalinoamericano (Vol. I, págs. 15-42). Rosario, Argentina: Ross.

Cepeda, J. (2015 marzo). Sentipensar ontológico. Un atisbo latinoamericano de la respuesta a la pregunta por el ser, bajo el horizonte kuscheano del filosofar. Ponencia presentada para el I Foro nacional de filosofía latinoamericana en la Universidad del Valle.

Cepeda, J. (2017). Sentipensar ontológico. Bogotá. AutoresEditores.

Estermann, J. (1998). Filosofía andina. Estudio intercultural de la sabiduría autóctona. Quito. Abya Yala.

Estermann, J. (2001). Filosofía. Curso integral de filosofía desde América Latina. Quito. Abya Yala.

Estermann, J. (2009). Filosofía andina. Sabiduría indígena para un mundo nuevo. La paz: Instituto Superior Ecuménico Andino de Teología. 
Estermann, J. (2011a). Entrevista a Josef Estermann. XIV Congreso Internacional de Filosofía Latinoamericana. Archivo Grupo de Investigación Tlamatinime sobre Ontología Latinoamericana y el semillero de Metafísica y Ontología de la Universidad Santo Tomás.

Estermann, J. (2011b). Ecosofía andina Un paradigma alternativo de convivencia cósmica y de Vivir Bien. En XIV Congreso Internacional de Filosofía Latinoamericana. Rehabilitar la tierra: Filosofía, Técnica y la Vida. Junio 29 a julio 22011. Universidad Santo Tomas.

Estermann, J. (2014). Lebenslauf Narrative. Universidad de Salsburgo. Austria, recuperada de https: //www.sbg.ac.at/syt/Team/Gastprofessuren/Estermann-CV_Publ_2014.pdf el 10 de Marzo de 2016.

Flores, G. (2011). Búsquedas actuales de la Filosofía andina. Lima: instituto de Investigaciones para la Paz, Cultura e Integración de América Latina.

Heidegger, M. (1998). Ser y tiempo. Bogotá, Colombia. Fondo de Cultura Económica.

Kusch, R. (1963, Nov). El mero estar de la cultura quichua. En Revista Américas. Vol. 15 (No 11) pp. 19-22. OEA. Washington.

Kusch, R. (2000). América profunda en Obras Completas. Vol. 2. Rosario. Fundación Ross.

Kapfhammer, W. (2012). Amazonian pain. Indigenous ontologies and Western ecospirituality. En Indiana. (No. 29) pp. 145-169. Ibero-Amerikanisches Institut Preußischer Kulturbesitz. Berlin. 
Leibniz, G. (1889). La Monadología. Madrid. Biblioteca Económica Filosófica. Recuperado en 14 de abril de 2016 de fama2.us.es/fde/ocr/2006/monadologia.pdf.

Marquínez, G. (1977). Metafísica desde Latinoamérica. Universidad Santo Tomás. Bogotá.

Miranda, J. (1996). Filosofía andina. Fundamentos, alteridad y perspectivas. La Paz: Hisbol/ Goethe institut.

Mejía, M. (2005). Hacia una filosofía andina. Doce ensayos sobre el componente andino de nuestro pensamiento. Lima. (Recuperado de http://lengamer.org/admin/language_folders/quechuadecusco/user_uploaded_files/li nks/File/Qhapaqkuna/Filosofia_Andina.pdf. El 4 de agosto de 2014)

Mejía, M. (2011). Teqse. La cosmovisión andina y las categorías quechuas como fundamentos para una filosofía peruana y de América Latina. Universidad Ricardo Palma. Lima.

Mejía, M. (2012). La cosmovisión andina y la reflexión filosófica. Conceptos andinos con los que se puede construir un filosofar. En J. Cepeda, \& M. Beuchot (Ed.), Aproximaciones indígenas a lo latinoamericano (Vol. I, págs. 83 - 123). Rosario, Argentina: Ross.

Ruz, Matías Omar, Rosolino, Guillermo, \& Schickendantz, Carlos (2008). Razón anamnética, sufrimiento ajeno y teodicea: Claves de lectura, logros y límites de la obra de Johann Baptist Metz. Teología y vida, 49(4), 575-603. Córdoba, Argentina. Universidad de Córdoba. Recuperado en 17 de mayo de 2016 de http://www.scielo.cl/scielo.php?script=sci_arttext\&pid=S0049-

$34492008000300002 \& \operatorname{lng}=$ es\&tlng=es. 10.4067/S0049-34492008000300002 
FUNDAMENTOS ONTOLÓGICOS EN LA FILOSOFIA ANDINA

Sobrevilla, D. (2008). La filosofía andina del P. Josef Estermann. Revista Solar, n. ${ }^{\circ}$ 4, año 4, Lima. 